\title{
Disruption of Protein Processing in the Endoplasmic Reticulum of DYT1 Knock-in Mice Implicates Novel Pathways in Dystonia Pathogenesis
}

\author{
Genevieve Beauvais, ${ }^{1}$ Nicole M. Bode, ${ }^{2}$ - Jaime L. Watson, ${ }^{1}$ Hsiang Wen, ${ }^{3}$ Kevin A. Glenn, ${ }^{3}$ Hiroyuki Kawano, ${ }^{4}$ \\ 으. Charles Harata, ${ }^{4}$ Michelle E. Ehrlich, ${ }^{5}$ and ${ }^{\circ}$ Pedro Gonzalez-Alegre ${ }^{1,6}$ \\ ${ }^{1}$ Perelman Center for Cellular and Molecular Therapeutics, The Children's Hospital of Philadelphia, Philadelphia, Pennsylvania 19104, ${ }^{2}$ Department of \\ Neurology and ${ }^{3}$ Department of Medicine, Carver College of Medicine, and ${ }^{4}$ Department of Molecular Physiology and Biophysics, the University of Iowa, \\ Iowa City, Iowa 52242, 5 Department of Neurology, Icahn School of Medicine at Mount Sinai, New York, New York 10029, and ${ }^{6}$ Department of Neurology, \\ Perelman School of Medicine at the University of Pennsylvania, Philadelphia, Pennsylvania 19104
}

Dystonia type 1 (DYT1) is a dominantly inherited neurological disease caused by mutations in TOR1A, the gene encoding the endoplasmic reticulum (ER)-resident protein torsinA. Previous work mostly completed in cell-based systems suggests that mutant torsinA alters protein processing in the secretory pathway. We hypothesized that inducing ER stress in the mammalian brain in vivo would trigger or exacerbate mutant torsinA-induced dysfunction. To test this hypothesis, we crossed DYT1 knock-in with p58(IPK)-null mice. The ER co-chaperone p58(IPK) interacts with BiP and assists in protein maturation by helping to fold ER cargo. Its deletion increases the cellular sensitivity to ER stress. We found a lower generation of DYT1 knock-in/p58 knock-out mice than expected from this cross, suggesting a developmental interaction that influences viability. However, surviving animals did not exhibit abnormal motor function. Analysis of brain tissue uncovered dysregulation of eiF $2 \alpha$ and Akt/mTOR translational control pathways in the DYT1 brain, a finding confirmed in a second rodent model and in human brain. Finally, an unbiased proteomic analysis identified relevant changes in the neuronal protein landscape suggesting abnormal ER protein metabolism and calcium dysregulation. Functional studies confirmed the interaction between the DYT1 genotype and neuronal calcium dynamics. Overall, these findings advance our knowledge on dystonia, linking translational control pathways and calcium physiology to dystonia pathogenesis and identifying potential new pharmacological targets.

Key words: dystonia; eif2alpha; endoplasmic reticulum; p58; proteomics; torsina

\section{Significance Statement}

Dystonia type 1 (DYT1) is one of the different forms of inherited dystonia, a neurological disorder characterized by involuntary, disabling movements. DYT1 is caused by mutations in the gene that encodes the endoplasmic reticulum (ER)-resident protein torsinA. How mutant torsinA causes neuronal dysfunction remains unknown. Here, we show the behavioral and molecular consequences of stressing the ER in DYT1 mice by increasing the amount of misfolded proteins. This resulted in the generation of a reduced number of animals, evidence of abnormal ER protein processing and dysregulation of translational control pathways. The work described here proposes a shared mechanism for different forms of dystonia, links for the first time known biological pathways to dystonia pathogenesis, and uncovers potential pharmacological targets for its treatment.

\section{Introduction}

Dystonia type 1 (DYT1) is a childhood-onset autosomaldominant disease characterized by abnormal, disabling, involun-

Received Feb. 24, 2016; revised July 6, 2016; accepted July 13, 2016.

Author contributions: G.B., K.A.G., N.C.H., and P.G.-A. designed research; G.B., N.M.B., J.L.W., H.W., H.K., K.A.G., N.C.H., and P.G.-A. performed research; G.B., J.L.W., K.A.G., M.E.E., and P.G.-A. analyzed data; G.B., K.A.G., N.C.H., M.E.E., and P.G.-A. wrote the paper.

This work was supported by the Stanley Fahn Award of the Dystonia Medical Research Foundation (P.G.A.), the US Department of Defense (Grant W81XWH-14-1-0282 to P.G.A. and Grant W81XWH-14-1-0301 to N.C.H.), and the National Institutes of Health (Grant NS081282 to M.E.E.). tary twisting movements (Bressman et al., 2000). The diseasecausing mutation in nearly all DYT1 patients is an in-frame GAG deletion in the TOR1A gene that results in the loss of a glutamic acid $(\Delta \mathrm{E})$ near the carboxy terminus of the protein torsinA (Ozelius et al., 1997). TorsinA is an endoplasmic reticulum (ER)-

\section{The authors declare no competing financial interests.}

Correspondence should be addressed to Pedro Gonzalez-Alegre, MD, PhD, 5062 Colket Translational Research Building, 3501 Civic Center Boulevard. Philadelphia, PA 19104. E-mail: pedro.gonzalez-alegre@uphs.upenn.edu. DOI:10.1523/JNEUROSCI.0669-16.2016

Copyright $\odot 2016$ the authors $\quad 0270-6474 / 16 / 3610245-12 \$ 15.00 / 0$ 
resident AAA protein (ATPase associated with various cellular activities). The function of torsinA within the ER and by what biological mechanism torsin $\mathrm{A}(\Delta \mathrm{E})$ triggers the disease remain unknown. Multiple studies have explored how torsin $\mathrm{A}(\Delta \mathrm{E})$ expression influences different aspects of neuronal physiology. For instance, torsin $\mathrm{A}(\Delta \mathrm{E})$ impairs synaptic vesicle recycling, calcium dynamics, and protein quality control mechanisms, among others (Pisani et al., 2006; Granata et al., 2009; Tanabe et al., 2009; Iwabuchi et al., 2013a). It is unclear, however, whether these biological events are under the direct control of torsinA function or if they represent indirect, nonspecific downstream effects of torsin $\mathrm{A}(\Delta \mathrm{E})$ expression.

A clue to understanding the specific biological function of tor$\sin \mathrm{A}$ derives from its subcellular localization. Torsin A resides in the ER lumen and the perinuclear space of the nuclear envelope (NE), whereas torsin $\mathrm{A}(\Delta \mathrm{E})$ concentrates in the $\mathrm{NE}$ (Gonzalez-Alegre and Paulson, 2004; Goodchild and Dauer, 2004; Naismith et al., 2004). In the heterozygous state, torsin $\mathrm{A}(\Delta \mathrm{E})$ recruits torsin $\mathrm{A}$ from the $\mathrm{ER}$ to the NE, causing a dominant-negative effect (Breakefield et al., 2001; Torres et al., 2004; Gonzalez-Alegre et al., 2005; Goodchild et al., 2005; Hewett et al., 2008). However, how this leads to ER dysfunction remains unknown. A plausible hypothesis, supported by data from multiple studies, is that torsin $\mathrm{A}(\Delta \mathrm{E})$ interferes with $\mathrm{ER}$ protein metabolism. The AAA domain of torsinA is closely related to $\mathrm{ClpB}$, a bacterial chaperone (Kock et al., 2006), and torsinA exhibits chaperone function in vitro (Burdette et al., 2010). DYT1 patient fibroblasts and cultured neurons from torsinA-null mice show impaired ER processing of a secreted reporter protein under homeostatic conditions (Hewett et al., 2007). TorsinA facilitates the retrotranslocation of mutant cystic fibrosis transmembrane conductance regulator to the cytosol for proteosomal degradation via ERAD (ER-associated degradation), a process impaired by torsin $\mathrm{A}(\Delta \mathrm{E})$ (Nery et al., 2011). Furthermore, fibroblasts and neurons from torsinA-null mice and homozygous Tor $1 a^{\Delta \mathrm{E} / \Delta \mathrm{E}}$ knock-in mice exhibit increased sensitivity to ER stress (Cho et al., 2014), although cells overexpressing torsinA have normal stress responses (Gordon et al., 2011). Finally, torsinA levels and torsin $\mathrm{A}(\Delta \mathrm{E})$ expression modulate the sensitivity of nematodes to ER stress (Chen et al., 2010; Thompson et al., 2014). These reports suggest that torsinA modulates ER cargo processing and export and the DYT1 mutation would impair this process. However, most of these studies are cell based and, in many cases, overexpression models. We hypothesize that increasing the import of misfolded proteins into the $\mathrm{ER}$ in the presence of torsin $\mathrm{A}(\Delta \mathrm{E})$ will cause $\mathrm{ER}$ stress in the mammalian brain in vivo, triggering the biological pathogenic cascade that leads to DYT1 and translating into abnormal motor function.

GRP78/BiP is the main chaperone that helps client ER proteins achieve native conformations as they enter the ER. The BiP co-chaperone p58(IPK) or p58 (also known as DNAJC3) assists the maturation of proteins entering the secretory pathway (Rutkowski et al., 2007). Expression of p58 influences resistance to ER stress in different tissues (Datta et al., 2010; Tao and Sha, 2011; Yang et al., 2011, Gao et al., 2012), suggesting that p58 modulates ER stress though its chaperone function. Therefore, this is an excellent model in which to test our hypothesis. Here, we crossed Tor $1 a^{+/ \Delta \mathrm{E}}$ (knock-in) with $p 58^{-/-}$(knock-out) mice to determine the consequences of this genetic interaction on motor function, ER stress pathways, and the neuronal proteome.

\section{Materials and Methods}

Generation of Torla ${ }^{+/ \Delta} ; p 58^{-1-}$ mice. Animal studies were carried at the University of Iowa and the Children Hospital of Philadelphia, and approved by the Institutional Animal Care and Use Committee in both institutions. Tor $1 a^{+/ \Delta \mathrm{E}}$ mice were generously provided by Dr. William Dauer (University of Michigan) (Goodchild et al., 2005). We obtained $p 58^{+1-}$ mice from Dr. Thomas Rutkowski (University of Iowa) (Rutkowski et al., 2007). Both lines were maintained on a C57BL/C6 background. We first crossed the two mouse lines to obtain Torla ${ }^{+/ \Delta \mathrm{E}}$; $p 58^{+1-}$ in the first generation, used as breeders. To generate experimental animals, we bred Tor $1 a^{+/ \Delta \mathrm{E}} ; p 58^{+/-}$with Tor1 $a^{+/+} ; p 58^{+/-}$. Animals were genotyped after weaning, and weighed weekly.

Acute slice preparation. Acute cerebellar slices were used for imaging the changes in cytoplasmic calcium concentration $\left(\left[\mathrm{Ca}^{2+}\right]_{c}\right)$. Three- to four-week-old mice were decapitated under intraperitoneal anesthesia with ketamine $(87.5 \mathrm{mg} / \mathrm{kg})$ and xylazine $(12.5 \mathrm{mg} / \mathrm{kg})$. The brain was quickly removed and was immersed in ice-cold, cutting solution (in mм: $125 \mathrm{NaCl}, 3 \mathrm{KCl}, 0.1 \mathrm{CaCl}_{2}, 5 \mathrm{MgCl}_{2}, 1.25 \mathrm{KH}_{2} \mathrm{PO}_{4}, 25 \mathrm{NaHCO}_{3}, 25$ D-glucose, 305-310 mOsm, pH 7.3-7.4). After midline section of the brain and coronal section rostral to the cerebellum, the remaining cerebellum and brainstem were glued on a magnetic specimen holder with cyanoacrylate glue, immersed in ice-cold cutting solution, and sliced sagittally at a thickness of $250 \mu \mathrm{m}$ with a vibrating-blade microtome (Leica Biosystems, Buffalo Grove, IL). Slices were transferred to a recording/imaging solution (in mM: $125 \mathrm{NaCl}, 3 \mathrm{KCl}, 2 \mathrm{CaCl}_{2}, 1.3 \mathrm{MgCl}_{2}, 1.25$ $\mathrm{KH}_{2} \mathrm{PO}_{4}, 25 \mathrm{NaHCO}_{3}, 25$ D-glucose, 305-310 mOsm, pH 7.3-7.4) at room temperature, trimmed to isolate the cerebella and kept in the same solution for $\sim 30 \mathrm{~min}$. Slices were then treated with tunicamycin at 1 $\mu \mathrm{g} / \mathrm{ml}$ (Sigma) or the vehicle (0.05\% DMSO) in prewarmed Minimum Essential Medium (MEM, Invitrogen-Thermo Fisher Scientific), for 120 min in a humidified culture incubator $\left(37^{\circ} \mathrm{C}, 95 \% \mathrm{O}_{2} / 5 \% \mathrm{CO}_{2}\right)$. After washing in MEM for 30-120 min in the culture incubator, a slice was loaded with $\left[\mathrm{Ca}^{2+}\right]_{\mathrm{c}}$ indicator Fluo-3-AM (10 $\mu \mathrm{M}$, Invitrogen-Thermo Fisher Scientific) in prewarmed MEM for $20 \mathrm{~min}$ in the culture incubator, rinsed in dye-free MEM for $10 \mathrm{~min}$ in the culture incubator, and observed in the recording solution in an imaging chamber (RC-26, Warner Instruments, Hamden, CT) at room temperature. The cutting and recording solutions were well saturated with $95 \% \mathrm{O}_{2} / 5 \% \mathrm{CO}_{2}$ throughout the procedures. The stock solutions of tunicamycin and Fluo-3-AM were prepared at $2 \mathrm{mg} / \mathrm{ml}$ and $2 \mathrm{~mm}$ in DMSO, resulting in the final DMSO concentrations of $0.05 \%$ and $0.5 \%$, respectively.

Calcium imaging. Sagittal cerebellar slices were imaged on an inverted microscope (Eclipse-TiE, Nikon, Melville, NY), using a $20 \times$ objective lens (S Plan Fluor, NA 0.45) or $4 \times$ objective lens (Plan Fluor, NA 0.13), a filter cube (490/20 nm excitation, $510 \mathrm{~nm}$ dichroic-long-pass, 520-nmlong-pass emission), and no intermediate coupler (i.e., $1 \times$ ), and an EMCCD camera (iXon ${ }^{\mathrm{EM}}+$ DU-860, Andor Technology, Belfast, UK). Fluo-3 was excited using a $490 \mathrm{~nm}$ light-emitting diode (LED, CoolLEDCustom Interconnect, Hampshire, UK) at $53 \%$ of maximal intensity. Slices were imaged at 100 frames/s and $1 \times 1$ binning, using a $20 \times$ lens and Solis software (Andor Technology), with a focus near the top surface of the slice. Exposure time was $9.67 \mathrm{~ms}$ and was limited to the period of image capture (LED was triggered by digital output from camera). Biased acquisition of fluorescence images was avoided by preselecting the area of slices for imaging based on DIC optics, i.e., in the absence of prior information about fluorescence images. Areas were selected based on the following indicators: clear identifications of molecular layer and granule cell layer of cerebellar cortex and the white matter, clear margin at the pial surface, lack of apparent mechanical damage and a lack of anchor mesh in the visible field. Fluorescence images were then acquired. In each image, the slice was placed such that the solution flows in the direction from the pial surface toward deeper layers of cerebellar cortex. $\left[\mathrm{Ca}^{2+}\right]_{c}$ transients were induced by applying $90 \mathrm{~mm} \mathrm{KCl}$ solution, $10 \mathrm{~s}$ after image acquisition was started, and continuously for $50 \mathrm{~s}$ thereafter. It was prepared by replacing equimolar $\mathrm{NaCl}$ by $\mathrm{KCl}$ in the recording solution. This solution was applied to the slices using the "Y-tube" method, a rapid local perfusion system that allows exchange of the external solution within $30 \mathrm{~ms}$ with an average travel rate of $\sim 100 \mu \mathrm{m} / \mathrm{ms}$ (Iwabuchi et al., 2013b). The Y-tube was connected to a suction bottle with a vacuum level of $300-400 \mathrm{mmHg}$, and the system was controlled by a Master- 8 pulse stimulator (AMPI). In addition, the entire imaging chamber was perfused with the recording solution continuously (bath perfusion). Photobleaching experiment was performed in the same way, but in the absence 
of $90 \mathrm{~mm} \mathrm{KCl}$ application. All imaging experiments were performed at room temperature. Images were analyzed using ImageJ and the Time Series Analyzer V3 plug-in. Images acquired during $1 \mathrm{~s}$ before stimulation were averaged to determine the image of prestimulus baseline intensity $\left(\mathrm{F}_{0}\right)$. The change in $\left[\mathrm{Ca}^{2+}\right]_{\mathrm{c}}$ was expressed as the fold-change in fluorescence intensity $(\mathrm{F})$ from baseline $\left(\mathrm{F}_{0}\right):\left(\mathrm{F}-\mathrm{F}_{0}\right) / \mathrm{F}_{0}=\Delta \mathrm{F} / \mathrm{F}_{0}$. A single polygonal region-of-interest (ROI) was placed on the molecular layer of the cerebellar slice, but excluding the pial surface, using the averaged $\mathrm{F}_{0}$ image. The intensity of the pixels in the ROI was averaged, and its time course was exported to Excel (Microsoft, Redmond, WA). The data were running-averaged with respect to time ( $\mathrm{rank}=10, n=21$ points) to reduce noises, and the peak amplitude was measured from the baseline without correcting for photobleaching.

Behavioral evaluations. Animals underwent weekly in-cage observation for grossly abnormal behavior before weighing. Open field. To measure spontaneous motor activity, mice were placed in a $25 \times 25 \mathrm{~cm}$ chamber and their movements tracked by the Viewpoint Videotrack software system as previously described (Martin et al., 2011). Total distance traveled was recorded in $10 \mathrm{~min}$ bins for a period of $30 \mathrm{~min}$. Rotarod. Mice were trained the first day for three trials on a rotarod apparatus going at a constant speed of $4 \mathrm{rpm}$ for $2 \mathrm{~min}$, then accelerating from $4 \mathrm{rpm}$ to $16 \mathrm{rpm}$ in $3 \mathrm{~min}$. The next following three days, animals were tested three times on the rotarod accelerating from $4 \mathrm{rpm}$ to $40 \mathrm{rpm}$ over $5 \mathrm{~min}$. The average time to fall off the rotarod was recorded for each day as previously reported (Bode et al., 2012). Beam walking. We used a 110 -cm-long beam with a flat surface $12 \mathrm{~mm}$ wide, placed $51 \mathrm{~cm}$ above a padded surface. A black escape box was placed at the end of the beam and a 60W lamp above the start point used as an aversive stimulus. On the first day, mice were placed in the black box for $5 \mathrm{~min}$ to acclimate. Then, the animal was placed on the beam at 6 inches distance of the box. On day two, we allowed the animals to acclimate for 2 min to the black box. The mouse was then placed at the beginning of the beam until each mouse completed two successful trials. On day three (test day), animals acclimated to the box for $2 \mathrm{~min}$ and walked on the beam for two consecutive trials. The time required to traverse the beam and number of foot slips were recorded and averaged for the two trials. Hindlimb clasping was scoped as described previously (Guyenet et al., 2010).

Human tissue. We obtained frozen brain tissue from three genetically confirmed DYT1 patients from the NICHD Brain and Tissue bank for developmental disorders in Baltimore (cerebellum and putamen from one, and only cerebellum or putamen from the other two). Their age at death was 67,77 and 90 years. Two of them have been previously reported (cases \#3 and \#5 in Paudel et al., 2014). The third case is a 67-yearold woman that developed dystonia at 12-15 years of age. She died of complications from cancer. Frozen putamenal ( $n: 5)$ and cerebellar $(n: 3)$ tissue from control human brains were kindly provided by the laboratory of Dr. Beverly Davidson (age range 68-91). Total proteins were extracted as described above. In brief, samples were homogenized for $10 \mathrm{~s}$ in RIPA buffer supplemented with proteases and phosphatase inhibitors using a hand homogenizer, followed by a step of sonication, and kept on ice for $30 \mathrm{~min}$ to complete the lysis. The soluble fraction of proteins was collected after centrifugation and processed for Western blotting.

Western blotting. Animals were killed by cervical dislocation and their brains extracted and dissected to collect different brain regions. Tissues were snap frozen in liquid nitrogen and stored at $-80^{\circ} \mathrm{C}$ until processed. For total protein extraction, the tissues were lysed in RIPA buffer completed with $\mathrm{N}$-ethylmaleimide and protease/phosphatase inhibitors as described previously (Gordon et al., 2012). After sonication, protein concentration was determined using the BCA assay, $20-40 \mu \mathrm{g}$ proteins were separated by SDS-PAGE and blotted with the following antibodies: TorsinA (ab34540, Abcam), p58 (2940, Cell Signaling Technology), BiP (3177, Cell Signaling Technology), Kdel (ADI-SPA-827, Enzo), Hspa9 (sc-13967, Santa Cruz Biotechnology), PERK (5683, Cell Signaling Technology), p-PERK (3179, Cell Signaling Technology), eIF2 $\alpha$ (sc-11386, Santa Cruz Biotechnology), p-eIF2 $\alpha$ (9712, Cell Signaling Technology), Akt (9272, Cell Signaling Technology), p-Akt (4060, Cell Signaling Technology), ATF4 (sc-200, Santa Cruz Biotechnology), ATF4 (10835-1-AP, Proteintech), CHOP (2895, Cell Signaling Technology), CHOP (sc-575, Santa Cruz Biotechnology), calbindin (sc-7691, Santa Cruz Biotechnol- ogy), calretinin (sc-50453, Santa Cruz Biotechnology) and $\alpha$-Tubulin (T5168, Sigma). Secondary HRP-linked goat anti-rabbit/mouse or donkey anti-goat antibodies were used, and signals were detected with the Chemidoc MP Imaging system from Biorad. To quantify the total load of high mannose glycoproteins we completed a lectin (GNA) blot as described previously (Mallinger et al., 2012). In brief, equal amounts of total protein for each lysate were resolved in SDS-PAGE and transferred to PVDF membranes, blocked and incubated with $6 \mu \mathrm{g}$ of snowdrop lectin (GNA; EY Laboratories, San Mateo, CA) for $1 \mathrm{~h}$ at room temperature and developed by chemiluminescence. For quantification, we used ImageJ to measure band intensity as described previously (Gordon et al., 2011). Control samples for each blot were assigned a density of 1 , and the relative density of other lanes was compared with the control. All samples were then normalized to a loading control.

Proteomic analysis. Cerebellum of 3 weeks-old mice were collected as above, snap frozen in liquid nitrogen collected and shipped in dry ice to Applied Biomics (Hayward, CA) for 2 dimensional fluorescence difference in gel electrophoresis (2D DIGE) and mass spectrometry analysis. For each gel, we used pooled samples from 2 animals for each genotype, all males. We followed the same protocol as described in torsinAexpressing cells (Martin et al., 2009). In summary, $30 \mu \mathrm{g}$ of lysates from each genotype were labeled with $\mathrm{Cy} 3$ and $\mathrm{Cy} 5$ dyes. Labeled samples were mixed and loaded on a $13 \mathrm{~cm}$ IPG strip, separated first by isoelectric focusing and then by molecular weight on a $12 \%$ SDS-PAGE. Image scans of the 2D-DIGE were taken using Typhoon TRIO (GE Healthcare). The scanned images were then analyzed on the Image QuantTL software (GE-Healthcare), and then subjected to in-gel analysis and cross-gel analysis using DeCyder software version 6.5 (GE-Healthcare). The ratio change of the protein differential expression was obtained from in-gel DeCyder software analysis, and 1.5 fold-change between genotypes was selected as differential expression threshold. The spots of interest were picked up by Ettan Spot Picker (GE Healthcare) followed by in-gel digestion with modified porcine trypsin protease (Trypsin Gold, Promega). The digested peptides were spotted on a MALDI plate, and MALDI-TOF and TOF/TOF (tandem MS/MS) performed on a 5800 mass spectrometer (AB Sciex). MALDI-TOF mass spectra were acquired in reflectronpositive ion mode, averaging 2000 laser shots per spectrum. TOF/TOF tandem MS fragmentation spectra were acquired for each sample, averaging 2000 laser shots per fragmentation spectrum on each of the 5-10 most abundant ions present in each sample (excluding trypsin autolytic peptides and other known background ions). The resulting peptide mass and the associated fragmentation spectra were submitted to GPS Explorer version 3.5 equipped with MASCOT search engine (Matrix science) to search the database of National Center for Biotechnology Information nonredundant (NCBInr) or Swiss Protein database. Searches were performed without constraining protein molecular weight or isoelectric point, with variable carbamidomethylation of cysteine and oxidation of methionine residues, and with one missed cleavage allowed in the search parameters. Candidates with either protein score CI\% or ion $\mathrm{CI} \%>95$ were considered significant.

Statistical analysis. We used GraphPad Prism 5 for statistical analysis. Statistical testing used for each experiment is indicated in the text or figure legends.

\section{Results}

Generation of DYT1 knock-in/p58 knock-out mice

We mated Tor $1 a^{+/ \Delta \mathrm{E}} ; p 58^{+/-}$with Tor $1 a^{+/+} ; p 58^{+/-}$mice to generate six potential genotypes. A total of 150 experimental animals were generated. We obtained half Tor $1 a^{+/ \Delta \mathrm{E}} ; p_{58^{-/-}}$animals than expected (Fig. $1 A$ ), suggesting a potential genetic interaction during development. For the rest of our experiments, we did not use heterozygote $p 58^{+/-}$mice. We focused on the other four genotypes for behavioral and molecular characterization. A previously described phenotypic trait of $p 58^{-1-}$ mice is lower body weight compared with p 58 hemizygous and WT mice. This phenotype was not modulated by the presence of the DYT1causing mutation (Fig. 1B). Because the human disease has a childhood/juvenile onset suggesting the occurrence of important 
A

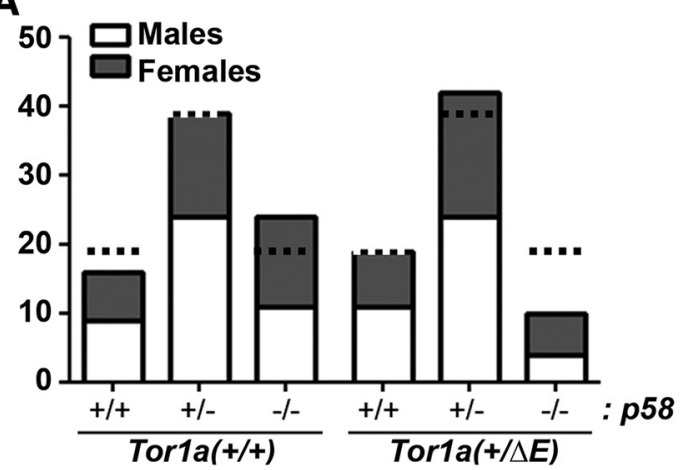

B

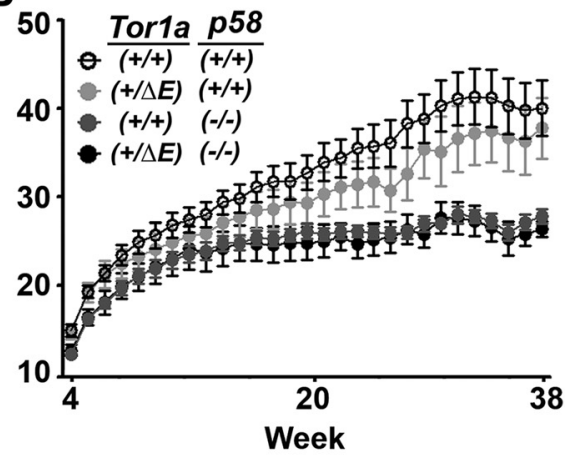

Figure 1. Generation of DYT1 knock-in/p58 knock-out mice. Tor1 $a^{+/ \Delta \mathrm{E}_{i}}, \mathrm{p} 58^{+/-}$and Tor1 $a^{+/+} ; p 58^{+/-}$mice were bred to generate six potential genotypes. A, Shown are the expected (dotted line) and obtained number of animals per genotype based on a normal Mendelian distribution. $\boldsymbol{B}$, Weekly weights are shown for the cohort of animals maintained until age 9 months. Two-way ANOVA for repeated measures showed a positive interaction of genotype and time $(p<0.001)$. Bonferroni's post test indicated an effect of the p58, but not the DYT1, genotype.

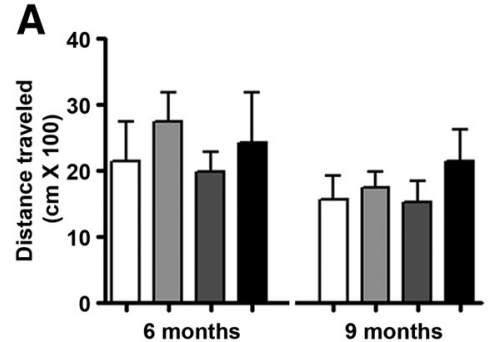

c

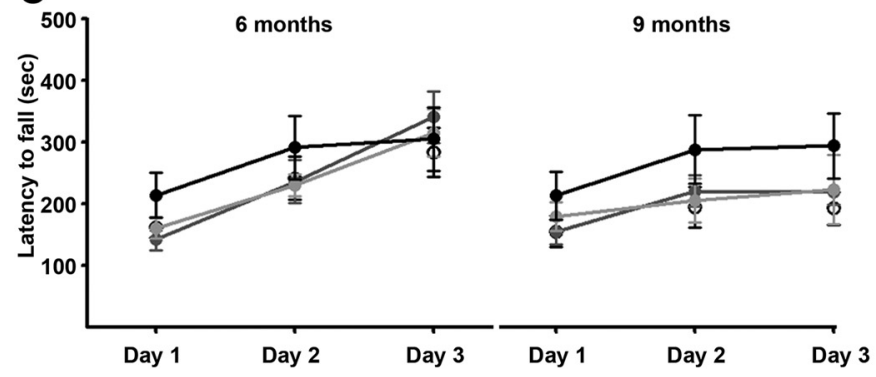

B

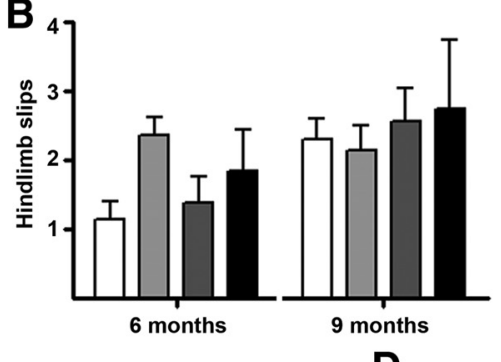

D

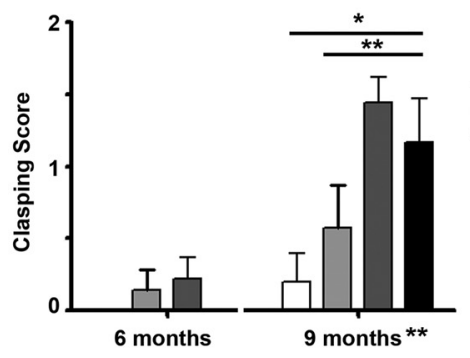

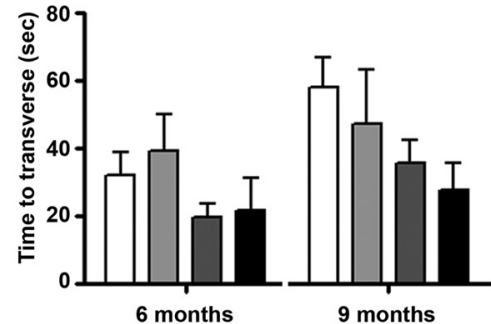

Tor1a $p 58$ $0 \square \overline{(+/+)} \frac{p 58}{(+/+)}(10)$ $\square(+/ \Delta E)(+/+)(7)$ $\square(+/+)(-/) \quad(9)$ - $(+/ \Delta E)(-/)$ (6)

Figure 2. Behavioral characterization of adult DYT1 knock-in/p58 knock-out and control mice. Mice of the four genotypes indicated were assessed at 6 and 9 months of age for motor function. $\boldsymbol{A}$, Spontaneous locomotor activity in the open field (shown as total distance traveled in $30 \mathrm{~min}$ ). $\boldsymbol{B}$, Beam-crossing task, measured as time to transverse (in seconds) and number of hindlimb slips. C, Performance on the rotarod on 3 consecutive trial days at ages 6 and 9 months. $\boldsymbol{D}$, Clasping score in the tail-hanging test as described in the Materials and Methods. Statistical differences were assessed by ANOVA with Tukey's post hoc test. ${ }^{*} p<0.05$; ${ }^{* *} p<0.01$.

pathogenic events at that developmental stage, a group of 80 animals were killed at 3 weeks of age (after weaning), whereas 70 mice were killed at 9 months.

\section{Loss of p58 does not induce gross motor dysfunction in Tor1a $^{+/ \Delta \mathrm{E}}$ mice}

Spontaneous locomotion was recorded at 6 and 9 months of age, revealing no differences by genotype (Fig. $2 A$ ). Similarly, we did not detect a genetic interaction between the Tor $1 a$ and $p 58$ genotypes on beam walking (Fig. $2 B$ ) or performance on the rotarod (Fig. 2C). $p 58^{-1-}$ mice trended to perform better in some of these tests, likely due to their smaller size, but this was not influenced by the presence of the DYT1 mutation. Mice lacking p58 showed hindlimb clasping that was not modified by the DYT1 genetic background (Fig. 2D). Overall, these results suggest that loss of p58 function is not sufficient to trigger significant motor dysfunction in DYT1 mice.

\section{Influence of torsin $\mathrm{A}(\Delta \mathrm{E})$ on the PERK-eiF2 $\alpha$ pathway}

Next, we investigated whether this genetic interaction influences torsinA levels and activation of the PERK-dependent ER-stress pathway (Fig. 3A) through Western blot analysis of cerebellar (Fig. 3) and striatal (data not shown, results consistent with cerebellar findings) lysates of 3-week-old and 9-month-old mice. Torla ${ }^{+/ \Delta \mathrm{E}}$ mice are known to have lower steady-state levels of total torsinA because the mutant protein is efficiently degraded by the proteasome through ERAD. We found that loss of p58 does not influence torsinA levels (Fig. $3 B, C$ ). In 3-week-old Tor1 $a^{+/ \Delta \mathrm{E}} ; p 58^{-1-}$ mice, phosphorylation of PERK (p-PERK/ PERK ratio) was reduced (Fig. $3 B, D$ ). These findings are the opposite of what would be expected in the presence of ER stress. We hypothesized that this could reflect an adaptive response by reducing the ER protein cargo (reduced demand). To test this possibility, we measured total high-mannose glycoprotein content, a biochemical signature of ER cargo, through lectin blotting in cerebellum. Consistent with this hypothesis, we found an additive reduction in high-mannose glycoproteins in loss of p58 and torsin $\mathrm{A}(\Delta \mathrm{E})$ expression in 3-week-old (data not shown) and 9-month-old mice (Fig. 3E). Interestingly, the reduction of ER cargo load correlates with an increment in CHOP levels (Fig. 3D), suggesting the possibility of enhanced age-related apoptosis. 


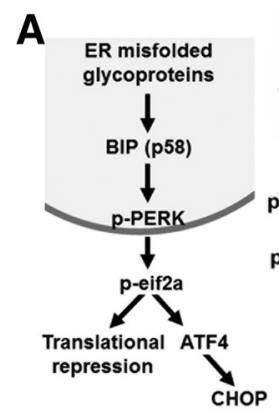

D
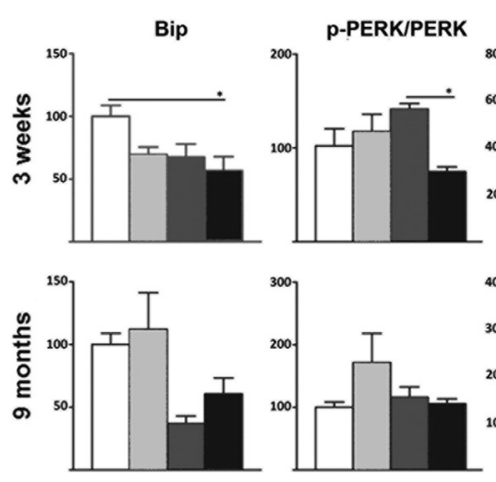

B 3 weeks

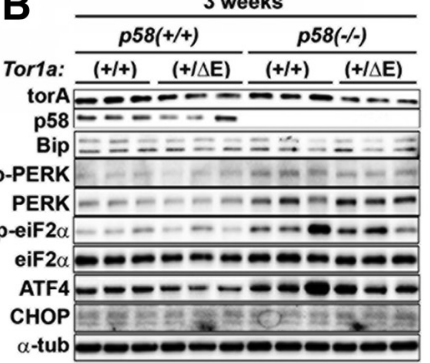

P-PERK/PERK
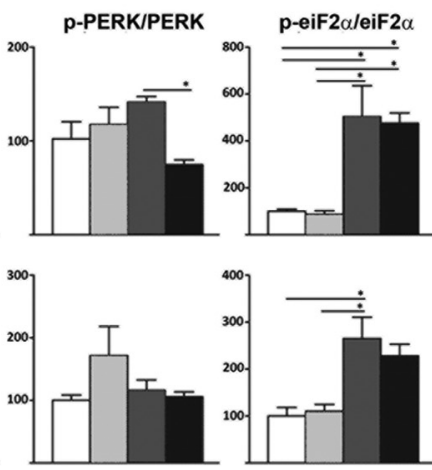

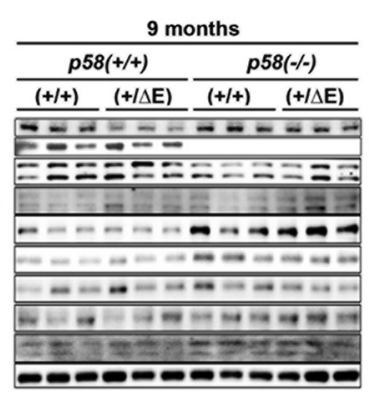

C
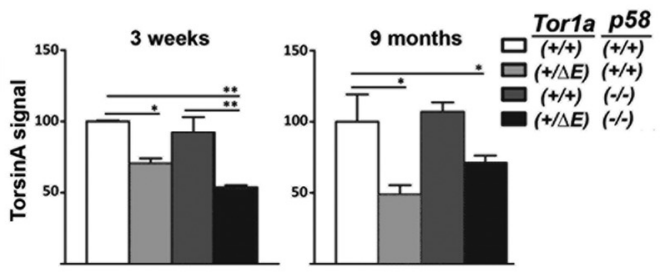

E
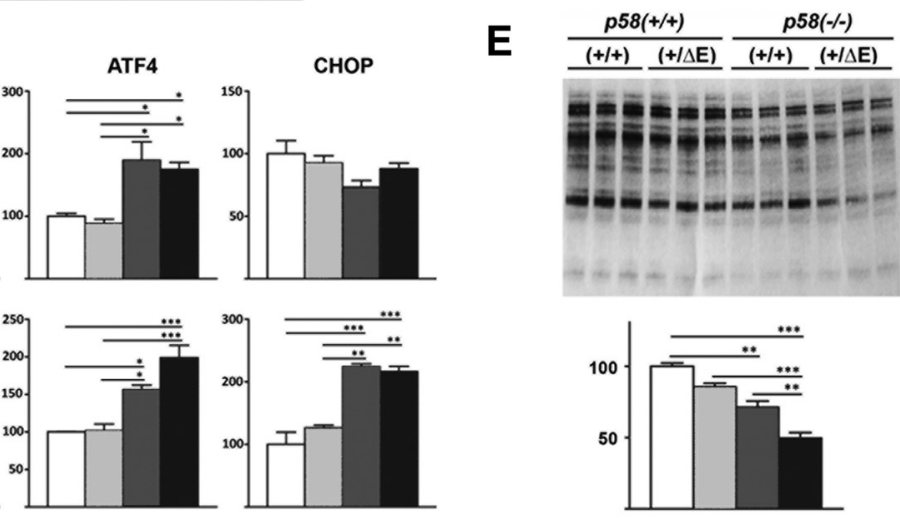
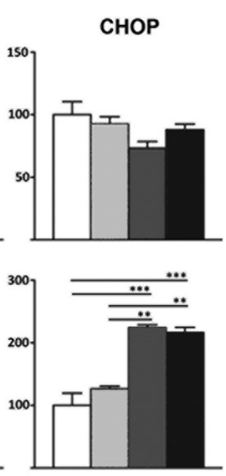

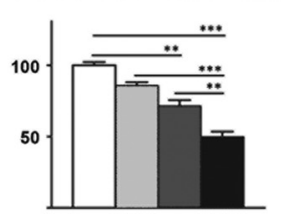

Figure 3. Analysis of the PERK- eiF2 $\alpha$ pathway. $\boldsymbol{A}$, Schematic representation of the ER and post-ER components of the PERK-eiF $2 \alpha$ ER stress pathway. $\boldsymbol{B}$, Western blot analysis in cerebellar tissue obtained from 3-week-old and 9-month-old mice for expression of the indicated proteins ( $n=3$ different animals per genotype). $C$, Quantification of total torsinA levels for each genotype as shown in $\boldsymbol{B}$. D, Quantification of the Western blot signal for different proteins shown in $\boldsymbol{B}$. For phosphorylated proteins, the phosphorylated to total protein ratio is shown. $\boldsymbol{E}$, Lectin blot of cerebellar lysates from three different animals per genotype (top) with quantification (bottom). Equal total protein amounts were loaded. Statistical differences were assessed by ANOVA with Tukey's post hoc test. ${ }^{*} p<0.05 ;{ }^{* *} p<0.01 ;{ }^{* * *} p<0.001$.

Despite the significant reduction in PERK phosphorylation in Tor1a ${ }^{+/ \Delta \mathrm{E}} ; p 58^{-1-}$ mice, we still detected increased phosphorylation of its, substrate eiF2 $\alpha$ (Fig. $3 B, D$ ). This finding suggests that, when the ER is challenged in the presence of mutant torsinA, there is PERK-independent eiF $2 \alpha$ phosphorylation. This could partly explain why, under homeostatic conditions, torsin $\mathrm{A}(\Delta \mathrm{E})$ does not significantly alter ER function but, upon the induction of stress, triggers abnormal signaling. Due to the potential relevance of this finding, we aimed to verify that torsin $\mathrm{A}(\Delta \mathrm{E})$ triggers eiF $2 \alpha$ phosphorylation in a different experimental system. We used brain tissue derived from transgenic rats that overexpress the human mutant TOR1A gene, including intros and exons and from its own promoter. We reasoned that increasing expression levels of torsin $\mathrm{A}(\Delta \mathrm{E})$ in this transgenic model over the physiological expression seen in the DYT1 knock-in mice, could trigger this effect even in the absence of an additional ER stressor. Consistent with findings in mice, transgenic rats had reduced levels of BiP and a trend toward reduced p-PERK/PERK (Fig. 4A, B). We next evaluated the phosphorylation state of PKR, another kinase that targets eiF2 $\alpha$. Similar to PERK, there was a reduction in p-PKR/ PKR ratio. Although an effect of these kinases over eiF $2 \alpha$ independent of this ratio cannot be excluded, PERK and PKR might not be responsible for the increased p-eiF2 $\alpha$ detected and perhaps there is a feedback downregulation of both as a consequence of the higher levels of p-eiF $2 \alpha$. Ultimately, p-eiF $2 \alpha$ is a key regulator of translation though a process that plays an increasingly recognized role in brain physiology (i.e., synaptic function). If $\operatorname{tor} \sin \mathrm{A}(\Delta \mathrm{E})$ leads to translational dysregulation, other pathways that control this process could also be abnormally activated. To test this possibility, we evaluated the Akt/mTOR pathway, another translational regulator, in neurons with evidence of crosstalk with the eIF2 $\alpha$ pathway (Mounir et al., 2011). Western blot analysis demonstrated significantly increased phosphorylation of Akt, mTOR, and 4ebp in DYT1 transgenic rats (Fig. 4A, B) and in torla ${ }^{+/ \Delta \mathrm{E}} ; p 58^{-1-}$ mice (data not shown).

Unbiased proteomic analysis identifies dysregulated proteins upon torsin $\mathrm{A}(\Delta \mathrm{E})$ expression

Most patients with DYT1 first develop dystonia at approximately age 10, suggesting the occurrence of key pathogenic events in the juvenile DYT1 brain. Consistent with this, there is already abnormal eiF2 $\alpha$ signaling in 3-week-old Tor1a ${ }^{+/ \Delta \mathrm{E}_{p}} ; 58^{-1-}$ mice and its downstream effects might be implicated in disease pathogenesis. Due to its role in translational regulation, we reasoned that a comparative proteomic analysis would be a reasonable approach to identify downstream effects of abnormal eiF $2 \alpha$ signaling in the stressed DYT1 brain. In a first 2D-DIGE, we compared the cerebellar proteome of Torla ${ }^{+/ \Delta \mathrm{E}}$ mice with wild-type littermates under homeostatic conditions (normal p58 expression). In a second gel, we evaluated samples from Torla ${ }^{+/ \Delta \mathrm{E}}$ and Torla ${ }^{+/+}$ animals in a $p 58^{-1-}$ background. This should allow us to detect protein expression changes caused by expression of torsin $\mathrm{A}(\Delta \mathrm{E})$ only when the ER is challenged (lack of p58, when we detected abnormal eiF2 $\alpha$ signaling), but not under homeostatic conditions (normal p58 expression). Automated quantitative analysis of the resulting 2D-DIGE images identified a total of 59 differentially expressed proteins with a change of at least 1.5 -fold among different conditions. We selected 23 spots for tandem MS/MS identification (Fig. 5A, Table 1). The results obtained indicated altered levels of some proteins, whereas others seemed to be selectively posttranslationally modified in Tor $1 a^{+/ \Delta \mathrm{E}} ; p 58^{-/-}$tissue (Fig. $5 B, C$ ). The two main functional clusters of proteins detected included ER protein metabolism and calcium-regulated proteins. Western blotting of selected proteins in tissue from 

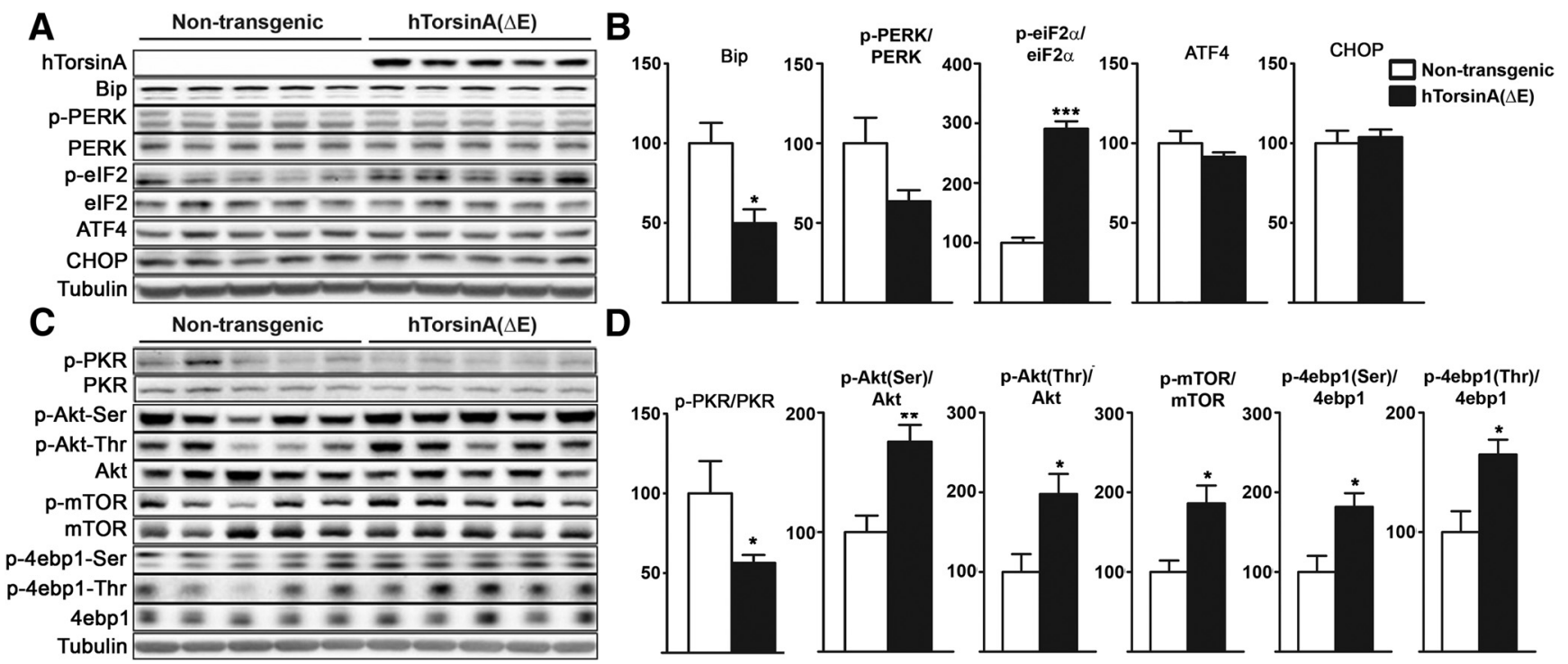

D

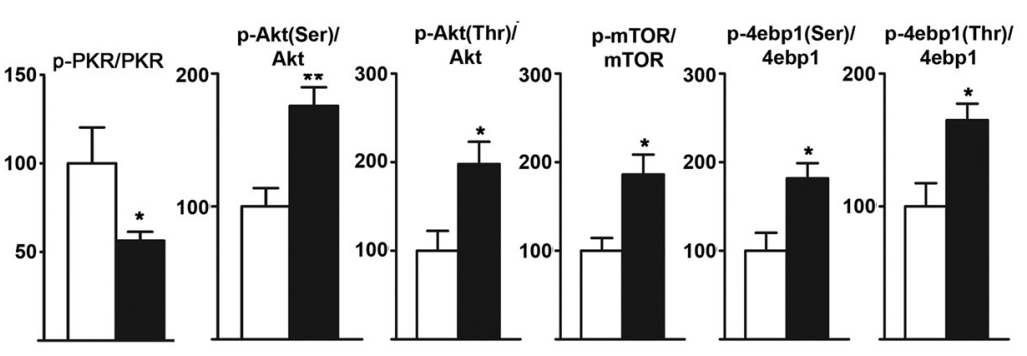

Figure 4. Analysis of the PERK- eiF2 $\alpha$ pathway in DYT1 transgenic rats. $A, C$, Western blot analysis of cerebellar lysates obtained from DYT1 transgenic rats and nontransgenic littermates for expression of the indicated proteins ( $n=5$ per genotype). $\boldsymbol{B}, \boldsymbol{D}$, Quantification of the experiments shown in $\boldsymbol{A}$ and $\boldsymbol{C}$. Statistical differences were assessed by ANOVA with Tukey's post hoc test. ${ }^{*} p<$ $0.05 ;{ }^{* *} p<0.01 ;{ }^{* * *} p<0.001$.

different animals was consistent with the results of proteomic analysis through trends or significant changes (Fig. 6).

\section{Functional analysis demonstrates abnormal calcium} dynamics in cerebellum associated with torsin $\mathrm{A}(\Delta \mathrm{E})$ expression and ER stress

Next, we evaluated the effects of torsin $\mathrm{A}(\Delta \mathrm{E})$ expression and $\mathrm{ER}$ stress on calcium physiology because the proteomic analysis pointed toward calcium dysregulation in Torla ${ }^{+/ \Delta \mathrm{E}} ; \mathrm{p}^{2} 8^{-1-}$ mice. Cerebellar slices from 3- to 4-week-old Torla ${ }^{+/ \Delta \mathrm{E}} ; p 58^{+/+}$ mice and control littermates $\left(\right.$ Torla $a^{+/+} ; p 58^{+/+}$) (Fig. $7 A, B$ ) were stimulated with $90 \mathrm{~mm} \mathrm{~K}{ }^{+}$solution and the changes in cytoplasmic calcium concentration $\left(\left[\mathrm{Ca}^{2+}\right]_{\mathrm{c}}\right)$ were evaluated in the molecular layer of cerebellar cortex, where dendrites of Purkinje neurons are located. The stimulation increased the $\left[\mathrm{Ca}^{2+}\right]_{c}$ transiently, when it was expressed as the fold change in fluorescence intensity $(F)$ from baseline $\left(F_{0}\right)\left(\Delta F / F_{0}\right.$; Fig. $\left.7 C, D\right)$. Under the control condition, in which the slices were treated with vehicle (DMSO), the Tor $1 a^{+/ \Delta \mathrm{E}} ; \mathrm{p5}^{+/+}$mice showed smaller peak amplitudes than the control mice (Fig. $7 E, F$ ). When the slices were under cellular stress by treatment with $1 \mu \mathrm{g} / \mathrm{ml}$ tunicamycin, the peak amplitude in control mice was reduced significantly, whereas that in Tor $1 a^{+/ \Delta \mathrm{E}_{p}} ; 58^{+/+}$mice was unchanged (Fig. $7 E, F)$. This resulted in a higher peak amplitude of the DYT1 than their WT counterparts during ER stress (Fig. $7 F$ ). These results in brain slices confirm the previous finding in cultured cells that $\operatorname{tor} \sin \mathrm{A}(\Delta \mathrm{E})$ expression influences the calcium dynamics (Iwabuchi et al., 2013a; Iwabuchi et al., 2013b) and, consistent with the proposed hypothesis, show a similar effect of the DYT1 protein on calcium dynamics as ER stress (peak reduction). Furthermore, in agreement with the proteomic findings, they demonstrate enhanced calcium dynamics under ER stress in DYT1 neurons.

Finally, to determine the potential significance of our findings, we obtained frozen putamenal and cerebellar tissue from human DYT1 patients and controls. Lysates were obtained and run in SDS-PAGE, followed by Western blot analysis of components of the eIF $2 \alpha$ pathway and candidate calcium-binding proteins. As shown in Figure 8, the comparison of expression levels for these candidate proteins between human DYT1 and control tissues was in agreement with findings in rodent models suggesting dysregulation of the eIF $2 \alpha$ pathway. We detected a potentially higher p-eIF2 $\alpha /$ eIF $2 \alpha$ ratio in DYT1 and possibly lower levels of the candidate calcium-binding proteins calbindin and calretinin in cerebellum. Statistical analysis was not performed due to the limited number of samples.

\section{Discussion}

In this work, we tested the interaction between defective protein folding in the neuronal $\mathrm{ER}$ and $\operatorname{tor} \sin \mathrm{A}(\Delta \mathrm{E})$ expression in vivo. These experiments yielded very interesting findings. First, the generation of Torla ${ }^{+/ \Delta \mathrm{E}} ; p 58^{-1-}$ animals was lower than expected. Second, we found an additive effect of $\operatorname{torsin} \mathrm{A}(\Delta \mathrm{E})$ expression and loss of p58 on reducing the ER glycoprotein load. Third, torsin $\mathrm{A}(\Delta \mathrm{E})$ increased eiF2 $\alpha$ phosphorylation in a PERKindependent manner. Fourth, the DYT1 brain had increased activation of the Akt/mTOR pathway. Finally, in the stressed ER, $\operatorname{tor} \sin \mathrm{A}(\Delta \mathrm{E})$ expression altered the brain proteome, indicating dysregulated ER protein processing and calcium dynamics, as confirmed in functional studies.

Most humans who carry the DYT1 mutation are asymptomatic and only $\sim 30 \%$ develop dystonia. We hypothesized that ER stress might trigger motor dysfunction in DYT1. An important observation of this study is that the genetic deletion of p 58 did not trigger significant motor dysfunction in Torla ${ }^{+/ \Delta \mathrm{E}}$ mice. A recent report described the generation of brain-specific conditional Tor1a-null mice that exhibit significant motor dysfunction and neuronal loss (Liang et al., 2014) with evidence of ER stress in degenerating neurons. However, this is not an exact genetic model of the disease and it would not allow us to explore the role of ER stress as a potential "second hit" for phenotypic penetrance. We decided to use DYT1 KI mice for this study, not only because they carry the same genetic variant as human patients, but also because they are a model of nonmanifesting mutation carriers. Nevertheless, neuronal ER stress did not trigger significant motor dysfunction in Tor $1 a^{+/ \Delta \mathrm{E}}$ mice. Several things could explain this finding. First, ER stress might not influence DYT1 pathogenesis or penetrance. Second, subtle motor dysfunction in Torla ${ }^{+/ \Delta \mathrm{E}}$; 


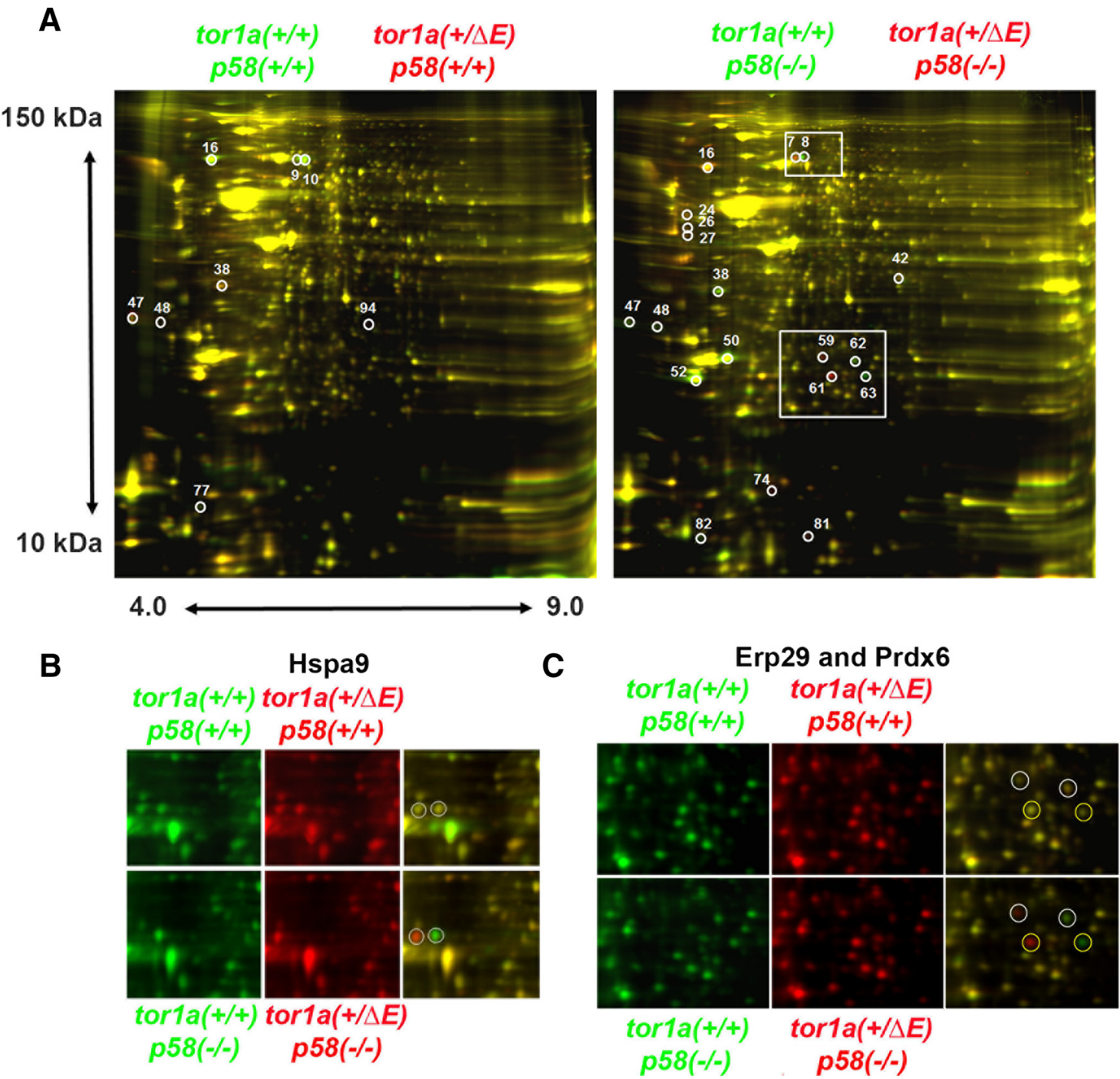

Figure 5. Proteomic analysis of cerebellar lysates from 3-week-old mice. $A$, Cerebellar lysates obtained from Tor $1 a^{+/ \Delta \mathrm{E}}$ or Tor $1 a^{+/+}$mice on a $p 58^{+/+}$or $p 58^{-/-}$background were processed as described in the experimental procedures. Lysates from Tor1a ${ }^{+/ \Delta \mathrm{E}}$ or Tor1a ${ }^{+/+}$mice were labeled with Cy3 and Cy5, respectively, mixed, and subjected to 2-DIGE (overlap images shown). A subset of the spots that were differentially expressed between the Tor1a ${ }^{+/ \Delta \mathrm{E}}$ and Tor1a ${ }^{+/+}$genotypes (circled) were picked for MS-MALDI-TOFF identification (spot IDs correspond to those shown in Table 1). $\boldsymbol{B}$, Magnification of the top boxed area in $\boldsymbol{A}$. The two circled proteins were identified as $\mathrm{Hspa9}$, suggesting posttranslational modification by Tor $1 a^{+/ \Delta \mathrm{E}}$ only in the $p 58^{-/-}$ background. C, Magnification of the bottom boxed area in $A$. The top two circled proteins were identified as Erp29 and the bottom two as Prdx6, also suggesting posttranslational modifications by Tor $1 a^{+/ \Delta \mathrm{E}}$ only in the $p 58^{-1-}$ background.

$p 58^{-1-}$ mice might have escaped detection by the behavioral assays performed and evaluation of additional animals might reveal an abnormality. Third, mice might not be an appropriate species to model human inherited dystonia. Finally, the reduced generation of Tor $1 a^{+/ \Delta \mathrm{E}} ; p 58^{-/-}$animals indicates a possible interaction during development causing a selection bias, with normal motor function in surviving animals. TorsinA is expressed during development and peaks from embryonic day 17 (E17) to postnatal day 7 (P7) (Vasudevan et al., 2006). There is activation of ER stress responses during embryonic brain development at E13 through E18 (Zhang et al., 2007). Loss of the ER chaperone ERdj4 reduces perinatal survival by half, demonstrating the importance of adaptation to ER stress in this developmental period (Fritz et al., 2014). Future studies will focus on the developmental process in Tor $1 a^{+/ \Delta \mathrm{E}} p 58^{-/-}$mice. In addition, evaluating the effect of one torsinA-null allele on the P58-null background will determine whether loss of viability results from torsinA haploinsufficiency or through a different mechanism.
Consequences of torsin $\mathrm{A}(\Delta \mathrm{E})$ expression in the ER: effects on protein processing and calcium signaling

We show that torsin $\mathrm{A}(\Delta \mathrm{E})$ modifies protein processing in the early secretory pathway. The first indication comes from the reduction in high-mannose (ER-resident) glycoprotein levels caused by torsin $\mathrm{A}(\Delta \mathrm{E})$, exhibiting an additive effect with p58. p58 is a co-chaperone that binds hydrophobic stretches in proteins upon ER entry and delivers them to BiP for folding. Losing this co-chaperone should increase the import of misfolded proteins and therefore lower the threshold for ER stress, as shown in other tissues. The mechanism via which this results in lower ER glycoprotein load needs to be explored, but it could be due to an adaptive response to chronic stress such as activation of the preemptive quality control pathway (Kang et al., 2006). Whatever the bases for this finding are, the fact that torsin $\mathrm{A}(\Delta \mathrm{E})$ expression and loss of p58 led to similar and additive findings suggests that they disrupt ER cargo maturation in a similar manner. The abnormal expression of the thioredoxin-dependent antioxidant 
Table 1. Differentially expressed proteins identified by MALDI-TOF/TOF

\begin{tabular}{|c|c|c|c|c|c|c|c|c|c|}
\hline \multirow[b]{2}{*}{ Spot } & \multirow[b]{2}{*}{ Top ranked protein } & \multirow{2}{*}{$\begin{array}{l}\text { Gene } \\
\text { Symbol }\end{array}$} & \multirow[b]{2}{*}{ MW } & \multirow[b]{2}{*}{$\mathrm{Pl}$} & \multirow{2}{*}{$\begin{array}{l}\text { Peptide } \\
\text { count }\end{array}$} & \multirow{2}{*}{$\begin{array}{l}\text { Protein } \\
\text { score Cl\% }\end{array}$} & \multirow{2}{*}{$\begin{array}{l}\text { Total } \\
\text { ion Cl\% }\end{array}$} & \multicolumn{2}{|c|}{ Volume change $^{*}$ Tor $1 a^{\Delta / E} /$ Tor1a $a^{+/ t}$} \\
\hline & & & & & & & & $p 58^{+/+}$ & $p 58^{-1-}$ \\
\hline 7 & Stress-70 protein, mitochondrial & Hspa9 & 73,416 & 5.8 & 19 & 100 & 100 & NS & 2.07 \\
\hline 8 & Stress-70 protein, mitochondrial & Hspa9 & 73,416 & 5.8 & 22 & 100 & 100 & NS & -2.72 \\
\hline 9 & Serum albumin & Alb & 68,648 & 5.8 & 29 & 100 & 100 & -2.12 & NS \\
\hline 10 & Serum albumin & Alb & 68,648 & 5.8 & 29 & 100 & 100 & -3.16 & NS \\
\hline 16 & Neurofilament light polypeptide & Nefl & 61,471 & 4.6 & 36 & 100 & 100 & -2.04 & 2.12 \\
\hline 24 & Histone-lysine N-methyltransferase & Setd7 & 40,481 & 4.5 & 15 & 100 & 100 & NS & 2.04 \\
\hline 26 & Brain acid soluble protein 1 & Basp1 & 22,074 & 4.5 & 12 & 100 & 100 & NS & 1.99 \\
\hline 27 & Brain acid soluble protein 1 & Basp1 & 22,074 & 4.5 & 8 & 100 & 100 & NS & 2.38 \\
\hline 38 & Carbonic anhydrase-related protein & Ca8 & 33,061 & 4.7 & 11 & 100 & 100 & 1.56 & -1.97 \\
\hline 42 & NAD-dependent protein deacetylase sirtuin-2 & Sirt2 & 43,228 & 5.2 & 26 & 100 & 100 & -1.73 & NS \\
\hline 47 & Acidic leucine-rich nuclear phosphoprotein 32 family member A & Anp32a & 28,520 & 4.0 & 9 & 100 & 100 & 1.8 & -2.17 \\
\hline 48 & Acidic leucine-rich nuclear phosphoprotein 32 family member A & Anp32a & 28,520 & 4.0 & 6 & 100 & 100 & NS & -2.19 \\
\hline 50 & Calretinin & Calb2 & 31,353 & 4.9 & 20 & 100 & 100 & NS & -2.38 \\
\hline 52 & Calbindin & Calb1 & 29,975 & 4.7 & 17 & 100 & 100 & NS & -2.4 \\
\hline 59 & Endoplasmic reticulum resident protein 29 & Erp29 & 28,805 & 5.9 & 9 & 100 & 100 & NS & 1.9 \\
\hline 61 & Peroxiredoxin-6 & Prdx6 & 24,855 & 5.7 & 18 & 100 & 100 & NS & 8.91 \\
\hline 62 & Endoplasmic reticulum resident protein 29 & Erp29 & 28,805 & 5.9 & 12 & 100 & 100 & NS & -2.39 \\
\hline 63 & Peroxiredoxin-6 & Prdx6 & 24,855 & 5.7 & 18 & 100 & 100 & NS & -3.41 \\
\hline 74 & Glia maturation factor beta & Gmfb & 16,712 & 5.1 & 6 & 100 & 100 & NS & 4.66 \\
\hline 77 & Gamma-synuclein & Sncg & 13,152 & 4.7 & 4 & 100 & 100 & -1.55 & 2.38 \\
\hline 81 & Neurogranin & Nrgn & 7,492 & 6.5 & 2 & 99 & 100 & NS & 1.87 \\
\hline 82 & Astrocytic phosphoprotein PEA-15 & Pea15 & 15,045 & 4.9 & 6 & 100 & 100 & NS & -1.68 \\
\hline 94 & 3-mercaptopyruvate sulfurtransferase & Mpst & 33,003 & 6.1 & 15 & 100 & 100 & 1.92 & -3.9 \\
\hline
\end{tabular}

MW, Molecular weight; Pl, isoelectric point; NS, Nonsignificant.

*Volume change in DYT1(KI) over DYT1(WT) either in p58(WT) (first column) or p58(K0) (second column) backgrounds.

A

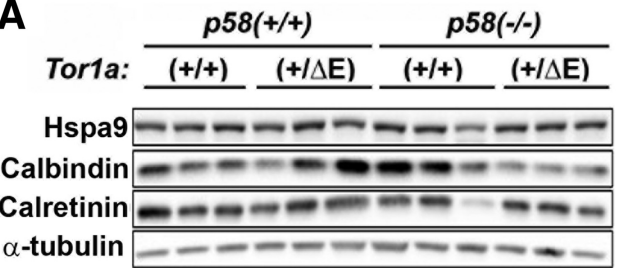

B

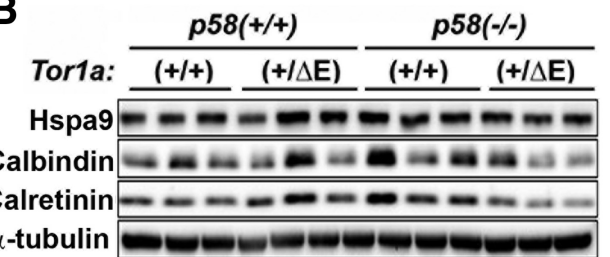

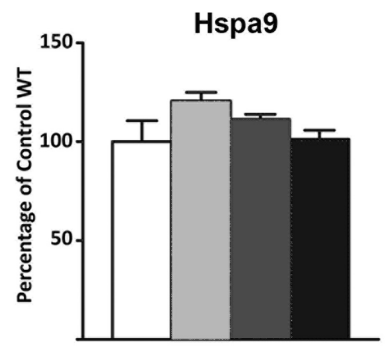
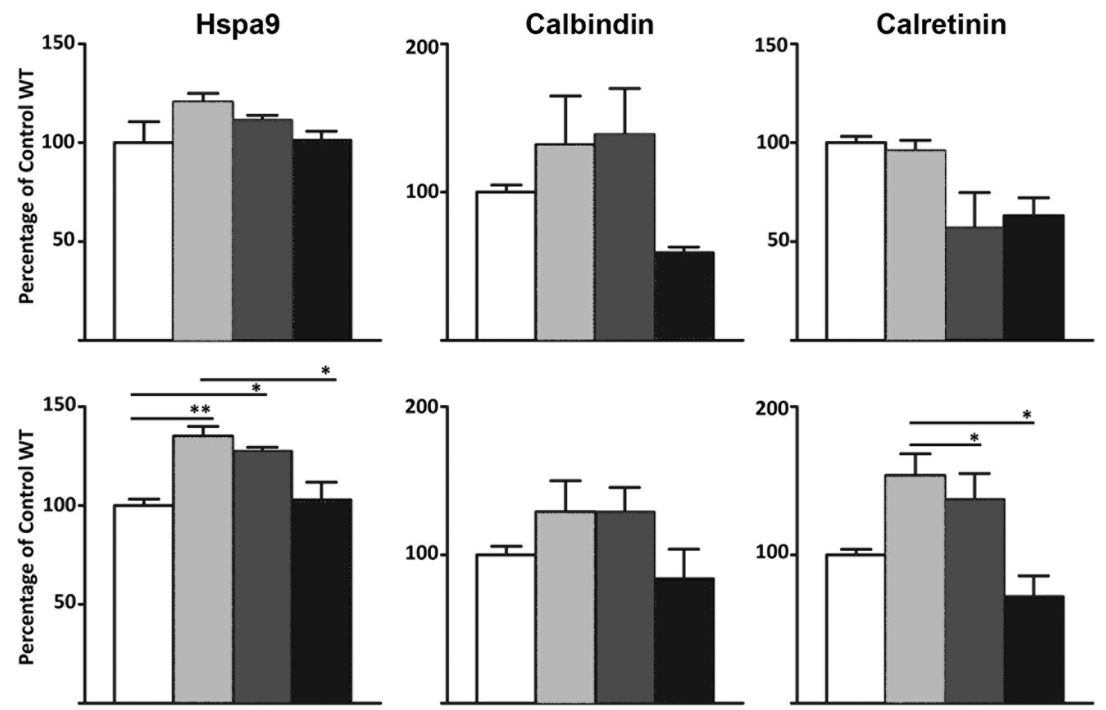

Figure 6. Western blot analysis of selected proteins identified by the proteomic analysis. Cerebellar lysates ( $n=3$ animals per genotype) were used for Western blot analysis in 3-week-old ( $\boldsymbol{A}$ ) and 9-month-old $(\boldsymbol{B})$ mice with the indicated antibodies. Statistical differences were assessed by ANOVA with Tukey's post hoc test. ${ }^{*} p<0.05 ;{ }^{* *} p<0.01$.

enzymes peroxiredoxin 6 and 3-mercaptopyruvate sulfurtransferase and the Hsp70 family chaperone HSPA9 found in the proteomic analysis add further support to a potential role of torsinA in oxidative folding and protein maturation. Interestingly, a previous unbiased analysis also found dysregulated expression of HSPA9 upon overexpression of torsinA $(\Delta \mathrm{E})$, but not torsi$\mathrm{nA}(\mathrm{WT})$ (Martin et al., 2009). This protein has been implicated in Parkinson's disease and is implicated in the cellular response to oxidative stress (Wadhwa et al., 2015). Future studies should further explore the potential role of HSPA9 in DYT1.

Despite the evidence for ER-protein-processing impairment, double mutant animals had reduced p-PERK/PERK compared with $\operatorname{Tor} 1 a^{+/+} ; p 58^{-1-}$, suggesting that torsin $\mathrm{A}(\Delta \mathrm{E})$ expression inhibits its activation. A potential mechanistic link to the phenomenon is offered by the proteomic analysis showing striking differential Erp29 expression or posttranslational modification in the double mutant brain. Erp29 is a chaperone that facilitates processing and transport of proteins in the early secretory pathway (Mkrtchian and Sandalova, 2006). Furthermore, Erp29 binds and regulates PERK expression (Farmaki et al., 2011) and promotes the biogenesis of ER client proteins such as CFTR, $\mathrm{ENaC}$, thyroglobulin, or $\mathrm{Cx} 43$ through a process regulated by 4-phenylbutyrate (Das et al., 2009; Suaud et al., 2011; Grumbach et al., 2014). Therefore, torsin $\mathrm{A}(\Delta \mathrm{E})$ could interfere with normal Erp29 function in the presence of ER stress, leading to the ERprotein-processing phenotypes described in different DYT1 
A

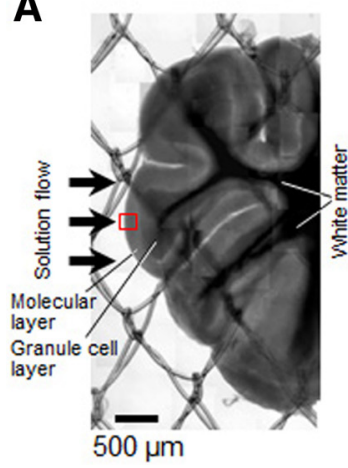

B

$\mathrm{F}_{0} \quad \Delta \mathrm{F} / \mathrm{F}_{0} \quad \Delta \mathrm{F} / \mathrm{F}_{0}$

Before stimulation Before stimulation During peak

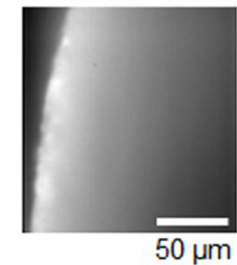

$50 \mu \mathrm{m}$

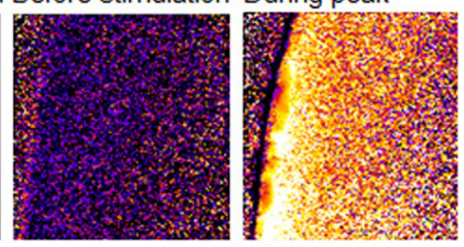

D

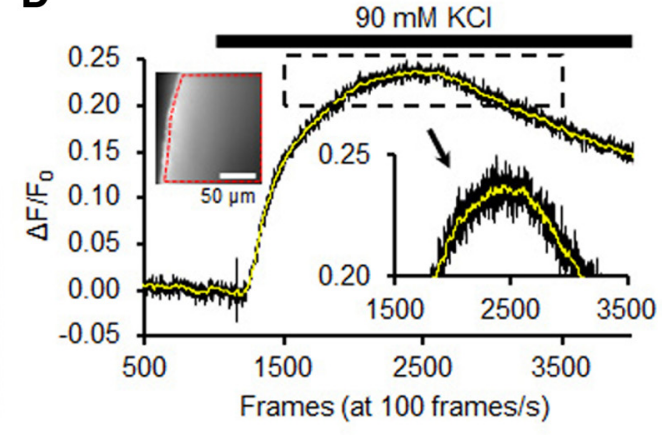

$\mathbf{F}$

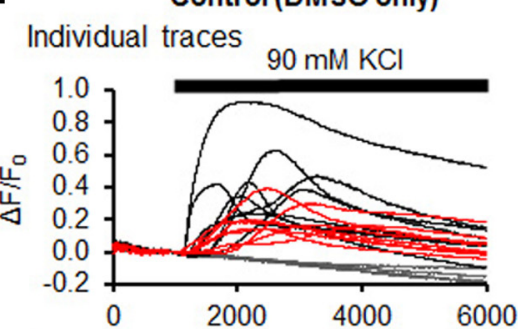

Averaged traces

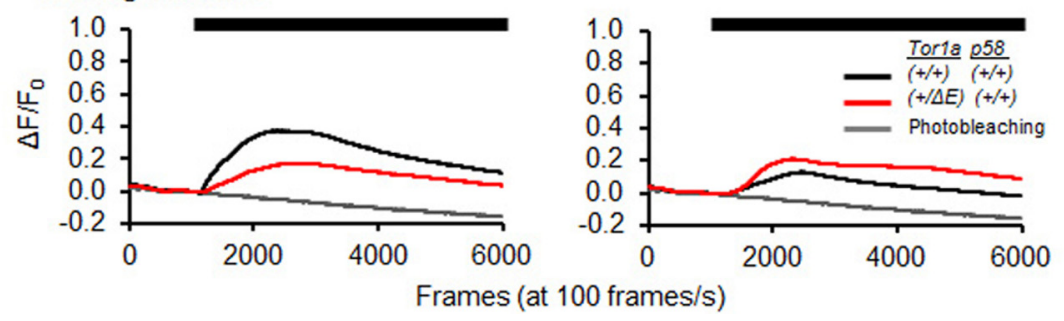

Tunicamycin

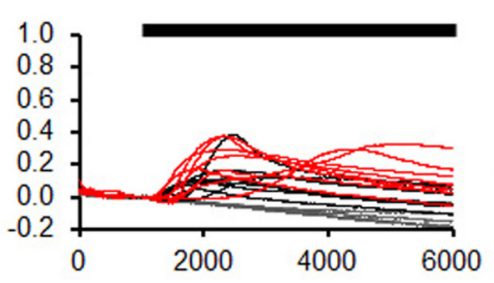

00

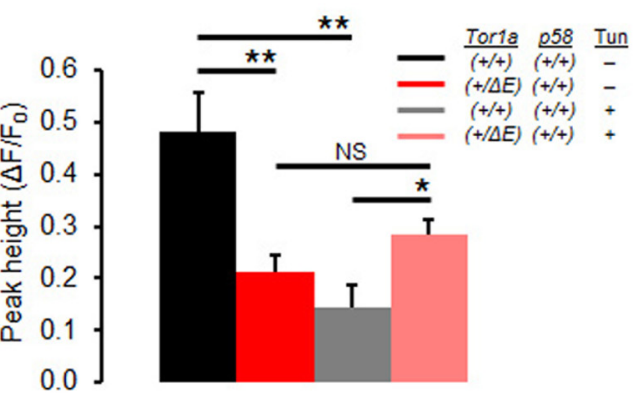

Figure 7. Analysis of calcium transients in cerebellar slices of 3- to 4-week-old mice. A, Montage showing a cerebellar slice in an imaging chamber. Three structures are visible in the differential interference contrast (DIC) optics: the molecular layer, the granule cell layer, and the white matter. The slice is anchored with a nylon mesh ( $\sim 1 \mathrm{~mm}$ intervals). Arrows show the direction of the $90 \mathrm{~mm} \mathrm{KCl}$ application. A red square shows a representative area for calcium imaging. $\boldsymbol{B}$, Resting fluorescence image of the cerebellar slice before stimulation $\left(F_{0}\right)$. $\boldsymbol{C}$, Changes in fluorescence intensity $\left(\Delta F / F_{0}\right)$ before $\mathrm{KCl}$ application (left) and during the peak response (right). $\boldsymbol{D}$, Representative $\Delta F / F_{0}$ trace. The left inset shows a region of interest used for calculating $\Delta F / F_{0}$. The right inset shows an enlarged trace near the peak, demonstrating the effect of running average on reducing noise for measuring the peak height (yellow trace). $\boldsymbol{E}$, Running-averaged $\Delta F / F_{0}$ traces under the control condition (left) and under a treatment with tunicamycin (right). Individual traces (top) and averaged traces (bottom). A single trace is derived from a single slice. $\boldsymbol{F}$, Peak heights of $\Delta F / F_{0}$ traces. Statistical significance was assessed using Student's $t$ test, with two-tailed $p$-values. ${ }^{*} p<0.05 ;{ }^{* *} p<0.01 ; n=7$ or 8 slices in each condition.

A

B
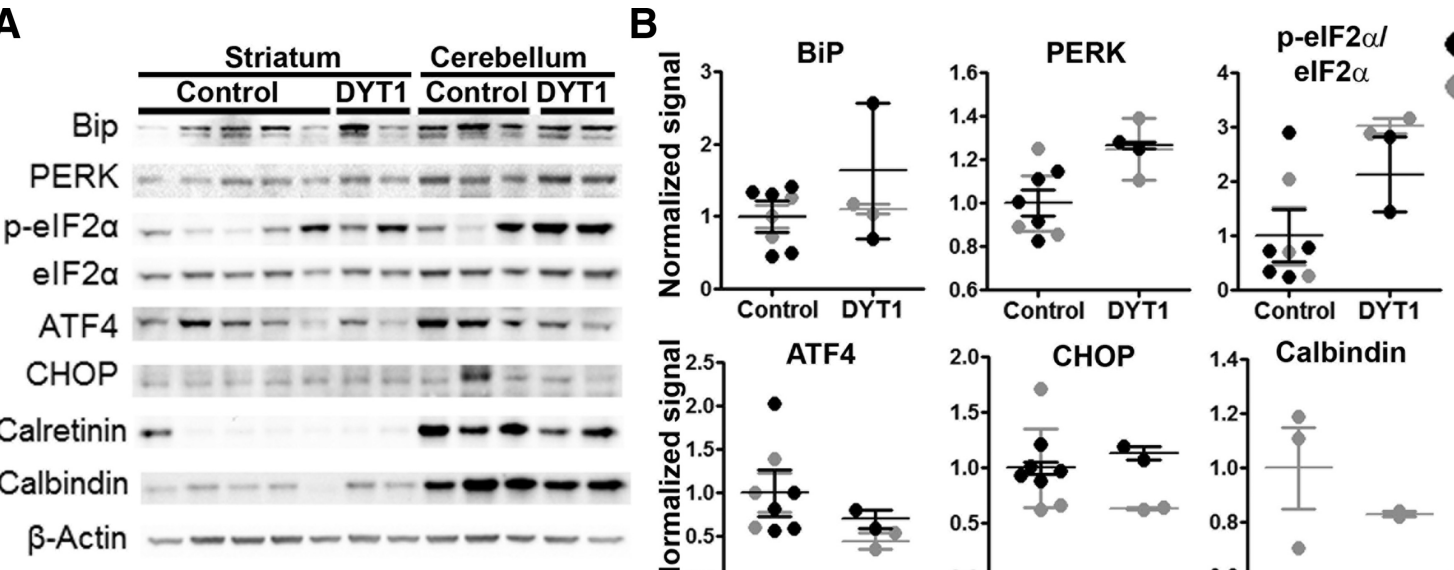

- Striatum

Cerebellum
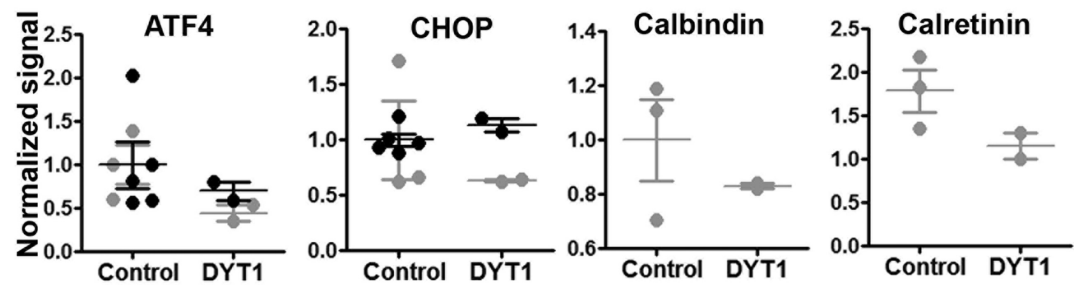

Figure 8. Analysis of protein expression in putamen and cerebellum of DYT1 patients and controls. A, Brain tissue from three DYT1 patients (cerebellum and putamen from one and only cerebellum or putamen from the other two) and controls (putamen from five subjects and cerebellum from three subjects) were subject to Western blot analysis to evaluate the PERK-eiF $2 \alpha$ pathway and dysregulated calcium-related proteins from the proteomic analysis in mice. $\boldsymbol{B}$, Quantification of expression levels normalized to the first control subject is shown. Statistical analysis was not performed due to the limited number of samples from each anatomical region. 
models. These include reduced secretion of ER cargo in cultured cells from DYT1 mice and patient fibroblasts (Hewett et al., 2007; Hewett et al., 2008), increased sensitivity to ER stress, and rescue of these phenotypes by 4-phenylbutyrate (Chen et al., 2010; Cho et al., 2014).

The proteomic analysis also found a cluster of calciumbinding or calcium-dependent proteins dysregulated by torsin $\mathrm{A}(\Delta \mathrm{E})$, including calbindin, calretinin, neurogranin, and Basp1. Previous physiological studies have shown abnormal calcium physiology in DYT1 neurons under normal conditions (Iwabuchi et al., 2013a; Iwabuchi et al., 2013b). Here, we confirm these findings and demonstrate a significantly abnormal response of neuronal calcium dynamics to ER stress in the DYT 1 cerebellum. How could torsinA $(\Delta \mathrm{E})$ lead to abnormal calcium signaling? Although there are various potential mechanisms, we find appealing the possibility of increased calcium permeability in the ER. Downregulation of ER lumenal co-chaperones leads to increased calcium leakage from the ER via Sec61 (Schorr et al., 2015). Based on the additive effects of the ER co-chaperone p58 and $\operatorname{tor} \sin \mathrm{A}(\Delta \mathrm{E})$ in the early secretory pathway, a similar mechanism could occur in DYT1 neurons. This would explain the defects on protein processing and calcium physiology caused by torsin $\mathrm{A}(\Delta \mathrm{E})$ though a common mechanism.

\section{$\operatorname{Tor} \sin \mathrm{A}(\Delta \mathrm{E})$-induced translational dysregulation}

An important contribution of this work is the potential implication of translational control in dystonia pathogenesis. It is possible that torsinA normally helps neurons adapt to different sources of stress by modulating translation to maintain normal function. This is very relevant because regulated translation in neurons is an increasingly recognized key event under physiological conditions such as synaptic plasticity (Costa-Mattioli et al., 2009). In the presence of the DYT1 mutation, torsin $\mathrm{A}(\Delta \mathrm{E})$ could malfunction by activating stress signals even under homeostatic conditions, leading to activation of the Akt/mTOR pathway and persistently enhanced eiF2 $\alpha$ phosphorylation. Both pathways could be independently activated by torsin $\mathrm{A}(\Delta \mathrm{E})$ or act in cis because there is known functional crosstalk between them (Kazemi et al., 2007; Mounir et al., 2011; Rajesh et al., 2015; Tenkerian et al., 2015). This unexpected link between DYT1 and translational regulation deserves further study.

\section{Hypothesis for DYT1 pathogenesis}

Based on our findings and prior reports, we propose a new mechanism of DYT1 pathogenesis. Data from different groups of investigators indicate that torsinA senses energy and redox state (Zhu et al., 2008; Zhu et al., 2010) and functions as a chaperone (Burdette et al., 2010). Therefore, torsinA could normally sense and signal the presence of ER stress, causing a targeted reduction in import and translation of ER cargo. In the presence of the DYT1 mutation, $\operatorname{tor} \sin \mathrm{A}(\Delta \mathrm{E})$ would aberrantly trigger this process even under homeostatic conditions. Furthermore, abnormal calcium permeability caused by the loss of chaperone function of torsinA could disrupt this important ER signaling mechanism. Notably, this hypothesis provides potential points of convergence for several forms of primary dystonia that should be explored in future experiments. The gene responsible for DYT16 dystonia, PRKRA, is a stress-modulated activator of the eiF $2 \alpha$ kinase PKR. Fibroblasts from DYT16 patients exhibit enhanced and persistent phosphorylation of PKR and eiF $2 \alpha$ under ER stress (Vaughn et al., 2015). DYT6 is caused by mutations in THAP1 (Fuchs et al., 2009), a protein also implicated in ER stress responses (Nayak et al., 2014). Finally, a growing list of dystonia genes are related to calcium physiology (Charlesworth et al., 2012; Domingo et al., 2016). Collectively, all of these findings suggest an intriguing link between ER protein processing and stress responses and translational regulation and calcium signaling in the pathogenesis of dystonia. This hypothesis requires experimental verification.

\section{References}

Bode N, Massey C, Gonzalez-Alegre P (2012) DYT1 knock-in mice are not sensitized against mitochondrial complex-II inhibition. PLoS One 7:e42644. CrossRef Medline

Breakefield XO, Kamm C, Hanson PI (2001) TorsinA: movement at many levels. Neuron 31:9-12. CrossRef Medline

Bressman SB, Sabatti C, Raymond D, de Leon D, Klein C, Kramer PL, Brin MF, Fahn S, Breakefield X, Ozelius LJ, Risch NJ (2000) The DYT1 phenotype and guidelines for diagnostic testing. Neurology 54:1746-1752. CrossRef Medline

Burdette AJ, Churchill PF, Caldwell GA, Caldwell KA (2010) The earlyonset torsion dystonia-associated protein, torsinA, displays molecular chaperone activity in vitro. Cell Stress Chaperones 15:605-617. CrossRef Medline

Charlesworth G, Plagnol V, Holmström KM, Bras J, Sheerin UM, Preza E, Rubio-Agusti I, Ryten M, Schneider SA, Stamelou M, Trabzuni D, Abramov AY, Bhatia KP, Wood NW (2012) Mutations in ANO3 cause dominant craniocervical dystonia: ion channel implicated in pathogenesis. Am J Hum Genet 91:1041-1050. CrossRef Medline

Chen P, Burdette AJ, Porter JC, Ricketts JC, Fox SA, Nery FC, Hewett JW, Berkowitz LA, Breakefield XO, Caldwell KA, Caldwell GA (2010) The early-onset torsion dystonia-associated protein, torsinA, is a homeostatic regulator of endoplasmic reticulum stress response. Hum Mol Genet 19: 3502-3515. CrossRef Medline

Cho JA, Zhang X, Miller GM, Lencer WI, Nery FC (2014) 4-Phenylbutyrate attenuates the ER stress response and cyclic AMP accumulation in DYT1 dystonia cell models. PLoS One 9:e110086. CrossRef Medline

Costa-Mattioli M, Sonenberg N, Richter JD (2009) Translational regulatory mechanisms in synaptic plasticity and memory storage. Prog Mol Biol Transl Sci 90:293-311. CrossRef Medline

Das S, Smith TD, Sarma JD, Ritzenthaler JD, Maza J, Kaplan BE, Cunningham LA, Suaud L, Hubbard MJ, Rubenstein RC, Koval M (2009) ERp29 restricts Connexin 43 oligomerization in the endoplasmic reticulum. Mol Biol Cell 20:2593-2604. CrossRef Medline

Datta R, Shah GN, Rubbelke TS, Waheed A, Rauchman M, Goodman AG, Katze MG, Sly WS (2010) Progressive renal injury from transgenic expression of human carbonic anhydrase IV folding mutants is enhanced by deficiency of p58IPK. Proc Natl Acad Sci U S A 107:6448-6452. CrossRef Medline

Domingo A, Erro R, Lohmann K (2016) Novel dystonia genes: clues on disease mechanisms and the complexities of high-throughput sequencing. Mov Disord 31:471-477. CrossRef Medline

Farmaki E, Mkrtchian S, Papazian I, Papavassiliou AG, Kiaris H (2011) ERp29 regulates response to doxorubicin by a PERK-mediated mechanism. Biochim Biophys Acta 1813:1165-1171. CrossRef Medline

Fritz JM, Dong M, Apsley KS, Martin EP, Na CL, Sitaraman S, Weaver TE (2014) Deficiency of the BiP cochaperone ERdj4 causes constitutive endoplasmic reticulum stress and metabolic defects. Mol Biol Cell 25: 431-440. CrossRef Medline

Fuchs T, Gavarini S, Saunders-Pullman R, Raymond D, Ehrlich ME, Bressman SB, Ozelius LJ (2009) Mutations in the THAP1 gene are responsible for DYT6 primary torsion dystonia. Nat Genet 41:286-288. CrossRef Medline

Gao D, Bambang IF, Putti TC, Lee YK, Richardson DR, Zhang D (2012) ERp29 induces breast cancer cell growth arrest and survival through modulation of activation of $\mathrm{p} 38$ and upregulation of ER stress protein $\mathrm{P} 58 \mathrm{IPK}$. Lab Invest 92:200-213. CrossRef Medline

Gonzalez-Alegre P, Paulson HL (2004) Aberrant cellular behavior of mu- 
tant torsinA implicates nuclear envelope dysfunction in DYT1 dystonia. J Neurosci 24:2593-2601. CrossRef Medline

Gonzalez-Alegre P, Bode N, Davidson BL, Paulson HL (2005) Silencing primary dystonia: lentiviral-mediated RNA interference therapy for DYT1 dystonia. J Neurosci 25:10502-10509. CrossRef Medline

Goodchild RE, Dauer WT (2004) Mislocalization to the nuclear envelope: an effect of the dystonia-causing torsinA mutation. Proc Natl Acad Sci U S A 101:847-852. CrossRef Medline

Goodchild RE, Kim CE, Dauer WT (2005) Loss of the dystonia-associated protein torsinA selectively disrupts the neuronal nuclear envelope. Neuron 48:923-932. CrossRef Medline

Gordon KL, Glenn KA, Gonzalez-Alegre P (2011) Exploring the influence of torsinA expression on protein quality control. Neurochem Res 36:452459. CrossRef Medline

Gordon KL, Glenn KA, Bode N, Wen HM, Paulson HL, Gonzalez-Alegre P (2012) The ubiquitin ligase F-box/G-domain protein 1 promotes the degradation of the disease-linked protein torsinA through the ubiquitinproteasome pathway and macroautophagy. Neuroscience 224:160-171. CrossRef Medline

Granata A, Schiavo G, Warner TT (2009) TorsinA and dystonia: from nuclear envelope to synapse. J Neurochem 109:1596-1609. CrossRef Medline

Grumbach Y, Bikard Y, Suaud L, Chanoux RA, Rubenstein RC (2014) ERp29 regulates epithelial sodium channel functional expression by promoting channel cleavage. Am J Physiol Cell Physiol 307:C701-C709. CrossRef Medline

Guyenet SJ, Furrer SA, Damian VM, Baughan TD, La Spada AR, Garden GA (2010) A simple composite phenotype scoring system for evaluating mouse models of cerebellar ataxia. J Vis Exp 39:pii:1787. CrossRef Medline

Hewett JW, Tannous B, Niland BP, Nery FC, Zeng J, Li Y, Breakefield XO (2007) Mutant torsinA interferes with protein processing through the secretory pathway in DYT1 dystonia cells. Proc Natl Acad Sci U S A 104: 7271-7276. CrossRef Medline

Hewett JW, Nery FC, Niland B, Ge P, Tan P, Hadwiger P, Tannous BA, Sah DW, Breakefield XO (2008) siRNA knock-down of mutant torsinA restores processing through secretory pathway in DYT1 dystonia cells. Hum Mol Genet 17:1436-1445. CrossRef Medline

Iwabuchi S, Kakazu Y, Koh JY, Harata NC (2013a) Abnormal cytoplasmic calcium dynamics in central neurons of a dystonia mouse model. Neurosci Lett 548:61-66. CrossRef Medline

Iwabuchi S, Koh JY, Wang K, Ho KW, Harata NC (2013b) Minimal Change in the cytoplasmic calcium dynamics in striatal GABAergic neurons of a DYT1 dystonia knock-in mouse model. PLoS One 8:e80793. CrossRef Medline

Kang SW, Rane NS, Kim SJ, Garrison JL, Taunton J, Hegde RS (2006) Substrate-specific translocational attenuation during ER stress defines a pre-emptive quality control pathway. Cell 127:999-1013. CrossRef Medline

Kazemi S, Mounir Z, Baltzis D, Raven JF, Wang S, Krishnamoorthy JL, Pluquet O, Pelletier J, Koromilas AE (2007) A novel function of eIF2alpha kinases as inducers of the phosphoinositide-3 kinase signaling pathway. Mol Biol Cell 18:3635-3644. CrossRef Medline

Kock N, Naismith TV, Boston HE, Ozelius LJ, Corey DP, Breakefield XO, Hanson PI (2006) Effects of genetic variations in the dystonia protein torsinA: identification of polymorphism at residue 216 as protein modifier. Hum Mol Genet 15:1355-1364. CrossRef Medline

Liang CC, Tanabe LM, Jou S, Chi F, Dauer WT (2014) TorsinA hypofunction causes abnormal twisting movements and sensorimotor circuit neurodegeneration. J Clin Invest 124:3080-3092. CrossRef Medline

Mallinger A, Wen HM, Dankle GM, Glenn KA (2012) Using a ubiquitin ligase as an unfolded protein sensor. Biochem Biophys Res Comm 418: 44-48. CrossRef Medline

Martin JN, Bair TB, Bode N, Dauer WT, Gonzalez-Alegre P (2009) Transcriptional and proteomic profiling in a cellular model of DYT1 dystonia. Neuroscience 164:563-572. CrossRef Medline

Martin JN, Wolken N, Brown T, Dauer WT, Ehrlich ME, Gonzalez-Alegre $P$ (2011) Lethal toxicity caused by expression of shRNA in the mouse striatum: implications for therapeutic design. Gene Ther 18:666-673. CrossRef Medline

Mkrtchian S, Sandalova T (2006) ERp29, an unusual redox-inactive mem- ber of the thioredoxin family. Antiox Redox Signal 8:325-337. CrossRef Medline

Mounir Z, Krishnamoorthy JL, Wang S, Papadopoulou B, Campbell S, Muller WJ, Hatzoglou M, Koromilas AE (2011) Akt determines cell fate through inhibition of the PERK-eIF2 $\alpha$ phosphorylation pathway. Sci Signal 4:ra62. CrossRef Medline

Naismith TV, Heuser JE, Breakefield XO, Hanson PI (2004) TorsinA in the nuclear envelope. Proc Natl Acad Sci U S A 101:7612-7617. CrossRef Medline

Nayak RR, Bernal WE, Lee JW, Kearns MJ, Cheung VG (2014) Stressinduced changes in gene interactions in human cells. Nucleic Acids Res 42:1757-1771. CrossRef Medline

Nery FC, Armata IA, Farley JE, Cho JA, Yaqub U, Chen P, da Hora CC, Wang Q, Tagaya M, Klein C, Tannous B, Caldwell KA, Caldwell GA, Lencer WI, Ye Y, Breakefield XO (2011) TorsinA participates in endoplasmic reticulum-associated degradation. Nat Commun 2:393. CrossRef Medline

Ozelius LJ, Hewett JW, Page CE, Bressman SB, Kramer PL, Shalish C, de Leon D, Brin MF, Raymond D, Corey DP, Fahn S, Risch NJ, Buckler AJ, Gusella JF, Breakefield XO (1997) The early-onset torsion dystonia gene (DYT1) encodes an ATP-binding protein. Nat Genet 17:40-48. CrossRef Medline

Paudel R, Kiely A, Li A, Lashley T, Bandopadhyay R, Hardy J, Jinnah HA, Bhatia K, Houlden H, Holton JL (2014) Neuropathological features of genetically confirmed DYT1 dystonia: investigating disease-specific inclusions. Acta Neuropathol Commun 2:159. CrossRef Medline

Pisani A, Martella G, Tscherter A, Bonsi P, Sharma N, Bernardi G, Standaert DG (2006) Altered responses to dopaminergic D2 receptor activation and N-type calcium currents in striatal cholinergic interneurons in a mouse model of DYT1 dystonia. Neurobiol Dis 24:318-325. CrossRef Medline

Rajesh K, Krishnamoorthy J, Kazimierczak U, Tenkerian C, Papadakis AI, Wang S, Huang S, Koromilas AE (2015) Phosphorylation of the translation initiation factor eIF2alpha at serine 51 determines the cell fate decisions of Akt in response to oxidative stress. Cell Death Dis 6:e1591. CrossRef Medline

Rutkowski DT, Kang SW, Goodman AG, Garrison JL, Taunton J, Katze MG, Kaufman RJ, Hegde RS (2007) The role of p58IPK in protecting the stressed endoplasmic reticulum. Mol Biol Cell 18:3681-3691. CrossRef Medline

Schorr S, Klein MC, Gamayun I, Melnyk A, Jung M, Schäuble N, Wang Q, Hemmis B, Bochen F, Greiner M, Lampel P, Urban SK, Hassdenteufel S, Dudek J, Chen XZ, Wagner R, Cavalié A, Zimmermann R (2015) Cochaperone specificity in gating of the polypeptide conducting channel in the membrane of the human endoplasmic reticulum. J Biol Chem 290: 18621-18635. CrossRef Medline

Suaud L, Miller K, Alvey L, Yan W, Robay A, Kebler C, Kreindler JL, Guttentag S, Hubbard MJ, Rubenstein RC (2011) ERp29 regulates DeltaF508 and wild-type cystic fibrosis transmembrane conductance regulator (CFTR) trafficking to the plasma membrane in cystic fibrosis (CF) and non-CF epithelial cells. J Biol Chem 286:21239-21253. CrossRef Medline

Tanabe LM, Kim CE, Alagem N, Dauer WT (2009) Primary dystonia: molecules and mechanisms. Nat Rev Neurol 5:598-609. CrossRef Medline

Tao J, Sha B (2011) Structural insight into the protective role of P58(IPK) during unfolded protein response. Methods Enzymol 490:259-270. CrossRef Medline

Tenkerian C, Krishnamoorthy J, Mounir Z, Kazimierczak U, Khoutorsky A, Staschke KA, Kristof AS, Wang S, Hatzoglou M, Koromilas AE (2015) mTORC2 balances AKT activation and eIF2alpha serine 51 phosphorylation to promote survival under stress. Mol Cancer Res 13:1377-1388. CrossRef Medline

Thompson ML, Chen P, Yan X, Kim H, Borom AR, Roberts NB, Caldwell KA, Caldwell GA (2014) TorsinA rescues ER-associated stress and locomotive defects in C. elegans models of ALS. Dis Model Mech 7:233-243. CrossRef Medline

Torres GE, Sweeney AL, Beaulieu JM, Shashidharan P, Caron MG (2004) Effect of torsinA on membrane proteins reveals a loss of function and a dominant-negative phenotype of the dystonia-associated DeltaEtorsinA mutant. Proc Natl Acad Sci U S A 101:15650-15655. CrossRef Medline

Vasudevan A, Breakefield XO, Bhide PG (2006) Developmental patterns of 
torsinA and torsinB expression. Brain Res 1073-1074:139-145. CrossRef Medline

Vaughn LS, Bragg DC, Sharma N, Camargos S, Cardoso F, Patel RC (2015) Altered activation of protein kinase PKR and enhanced apoptosis in dystonia cells carrying a mutation in PKR activator protein PACT. J Biol Chem 290:22543-22557. CrossRef Medline

Wadhwa R, Ryu J, Ahn HM, Saxena N, Chaudhary A, Yun CO, Kaul SC (2015) Functional significance of point mutations in stress chaperone mortalin and their relevance to Parkinson disease. J Biol Chem 290: 8447-8456. CrossRef Medline

Yang H, Liu R, Cui Z, Chen ZQ, Yan S, Pei H, Li B (2011) Functional characterization of 58-kilodalton inhibitor of protein kinase in protecting against diabetic retinopathy via the endoplasmic reticulum stress pathway. Mol Vis 17:78-84. Medline

Zhang X, Szabo E, Michalak M, Opas M (2007) Endoplasmic reticulum stress during the embryonic development of the central nervous system in the mouse. Int J Dev Neurosci 25:455-463. CrossRef Medline

Zhu L, Wrabl JO, Hayashi AP, Rose LS, Thomas PJ (2008) The torsin-family $\mathrm{AAA}+$ protein OOC-5 contains a critical disulfide adjacent to Sensor-II that couples redox state to nucleotide binding. Mol Biol Cell 19:35993612. CrossRef Medline

Zhu L, Millen L, Mendoza JL, Thomas PJ (2010) A unique redox-sensing sensor II motif in TorsinA plays a critical role in nucleotide and partner binding. J Biol Chem 285:37271-37280. CrossRef Medline 